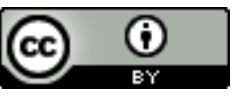

\title{
Riku Kauhanen
}

\section{Katsaus valkoisten ja vapaussodan perintöön}

\begin{abstract}
ABSTRAKTI / ABSTRACT
Vapaussodan perintö on keskeinen osa Suomen sisällissodan voittaneen valkoisen puolen identiteetinrakennusta ja historiakuva, joka vallitsi maailmansotien välisenä aikana. "Vapaussotamyytin" luominen alkoi jo sisällissodan lopulla vuonna 1918 ja laajemmassa näkökulmassa se ulotettiin tulkinnoissakattamaan menneisyydestä niin vanhempi sotabistoria kuin sortokaudet sekä sisällissotaa seuranneelta ajalta heimosodat. Varsinainen sotamuistojen moniulotteinen keruntoiminta alkoi jo sodan lopulla, tähdäten punaisen puolen rikollisunden sekä venäläisten kanssa tehdyn yhteistyön alleviivaamiseen.

Vapaussodan muistelun kannalta olennaisia olivat muistin paikkoina sankarihautausmaat ja muistomerkit sekä tietyt sodan paikalliset tai valtakunnalliset merkkipäïät, joista tärkeimpiä olivat tammisunnuntai sekä sodan päättymispäivä 16. tonkokunta. Valkoisten perinnön ja vapaussodan muistojen kerun kiihtyi 1930-luvulla, ja samalla erilaiset tahot pyrkivät omimaan vapaussodan valkoisen tulkinnan omakseen, käytännössä kilpaillen muiden keruuta harjoittavien tahojen kanssa. Valkoinen vapaussotatulkinta piti pintansa vielä toisen maailmansodan jälkeenkin, mutta kylmä sota merkitsi punaisen tulkinnan läpimurtoa julkisundessa.
\end{abstract}

historiapolitiikka, historiakulttuuri, muistomerkit, sankarihaudat, sotamuistot, sisällissota, sotilasmusiikki,valkoiset, vapaussota

Riku Kauhanen, Turun yliopisto, rpkauh@utu.fi 


\section{Johdanto}

Tässä artikkelissa luon katsauksen Suomen sisällissodan 1918 voittaneen osapuolen, valkoisten, perintöön, joka kattaa muistamisen muodot, keinot ja välineet. Tarkoitus ei ole löytää uusia tuloksia tai näkökulmia, vaan jo tehtyyn tutkimukseen sekä aikalaislähteisiin nojaten esitellä aihetta. Käytän aikalaislehdistöä katsauksessa lähinnä lainaamalla aikakauden ja keskustelun hengen hyvin tiivistäviä kirjoituksia. Koska artikkelissa käsitellään sisällissotaa nimenomaan valkoisesta näkökulmasta, käytän tekstissä usein alkuperäislähteiden mukaisesti termiä "vapaussota", joka samalla pitää sisällään siihen alkuperäisessä yhteydessä liitetyt arvolataukset.

En tarkastele punaista näkökulmaa, koska tässä julkaisussa on Anne Heimon ja Tiina Lintusen artikkeli "Monisärmäinen punainen historia - 100 vuotta punaisten historiakulttuuria" aiheesta, enkä punaisten tulkinnan murrosta ja nousua valtavirtaan toisen maailmansodan jälkeen, vaikka se vastaavasti tiesikin valkoisen tulkinnan joutumista marginaaliin. Pikemminkin tarkastelen valkoisten konkreettisten muistojen kohtelua sekä valkoisen tulkinnan selviytymistä sekä vastavetoja punaiselle voimistuvalle tulkinnalle. Kysymys ei usein ollut akateemisesta argumentoinnista, vaan mielikuvien käytöstä.

Valkoinen perintö on hyvin laaja käsite, eikä sen kaikkien muotojen ja vaiheiden tarkastelulle ole tilaa tai mahdollisuuksia. Rajaan muun muassa runouden ja kirjallisuuden katsauksen ulkopuolelle aiheiden laajuuden vuoksi. Kirjallisuus olisi hyvin työläs käsiteltävä koska erilaisia pienpainatteita, historiikkeja ja kaunokirjallisia kuvauksia julkaistiin (ja julkaistaan) valtavasti. Sodan muistoja ja perintöä kartoittava Suomen vapaussota -lehti listasi jo maaliskuussa 1933 kaikkiaan 122 suomen- ja ruotsinkielistä vapaussotaa käsittelevää teosta: lehti totesi listauksen pahasti puutteelliseksi, jopa tärkeiden teosten osalta, ja lupasi täydentää sitä myöhemmin ${ }^{1}$. Nykyään monet vanhat teokset ovat bibliofiilisiä harvinaisuuksia.

Valkoisten sisällissotatulkintaa, "vapaussotamyyttiä" on tutkittu 2000-luvulla ahkerasti ja aihetta on tarkasteltu laaja-alaisesti. Merkittävimpinä teoksina mainittakoon Miika Siirosen monipuolinen Valkoiset. Vapaussodan perintö (2012) ${ }^{2}$ joka käyttää ja tutkii etenkin Iisalmea tapahtumaympäristönä. Aapo Roselius on tarkastellut valkoista perintöä perinpohjaisesti teoksessa Isänmaallinen kevät: vapaussotamyytin alkulähteillä (2013) ${ }^{3}$, käyttäen esimerkkinä etenkin Loimaan vaiheita. Juha Poteri on tutkinut valkoisille tärkeää sankarivainajien käsitettä vuonna 2009 väitöskirjassaan Sankarihautaus vapaussodassa - valkoisten kaatuneiden bautaaminen Suomessa vuonna $1918^{4}$ ja artikkelissaan "Valkoisten sankarihautajaiset" teoksessa Sisällissota 1918 ja kirkkeo5. Tuomas Tepora on taas käsitellyt sankarivainajien ja Suomen nationalismin suhdetta laajemmin teoksessaan Sinun puolestas eläa ja kuolla: Suomen liput, nationalismi ja veriubri 1917-1945 (2011). "Vapaussodan sankarivainajat" olivat olennaisia niin valtakunnallisesti kuin paikallisesti valkoisten historiatulkinnan tukena: uhri velvoitti.

Sisällissodan "100-vuotisjuhlat" vuonna 2018 tuottivat suuren määrän muistitietoon, sisällissodan perintöön ja ylipäätään itse sotaan liittyviä julkaisuja. Valkoisten muistipolitiikkaa käsiteltiin esimerkiksi Tuomas Teporan ja Aapo Roseliuksen toimittamassa artikkelikokoelmassa The Finnish Civil War 1918: History, Memory, Legacy (2014), joka julkaistiin vuonna 2018 suomennettuna ja täydennettynä laitoksena Rikkki revitty maa: Suomen sisällissodan kokemukset ja perintȫ. Lisäksi 2018 julkaistiin Anne Heimon, Ulla Aatsingin ja Tiina Lintusen toimittamana artikkelikokoelma Sisällissodan jäljet sekä sodan muistipolitiikan hyvin tiivistävä Seppo Hentilän teos Pitkät varjot: muistamisen historia ja politiikkea?. Monet kirjoittajista ovat myös kirjoittaneet eri artikkelikokoelmiin. 


\section{Mitä oli valkoinen perintö?}

Valkoinen perintö voidaan jakaa karkeasti kahteen luokkaan: henkiseen perintöön, joka kattoi esimerkiksi propagandan kaikissa muodoissaan, kirjallisuuden, runot ja laulut sekä juhlat ja muistopäivät. Fyysinen perintö kattoi muun muassa muistoesineet ja muistomerkit. Fyysisen ja henkisen perinnön keskeiseksi läpileikkauspisteeksi muodostuivat sankarihaudat, konkreettiset isänmaan uhrin paikat, joissa voitiin viettää muistotilaisuuksia, vapausjuhlia itsensä uhranneiden vapaussoturien luona. Onkin ymmärrettävä, että valkoinen perintö oli ja on hyvin laaja, hajanainen ja muuttuva käsite.

Sisällissodan valkoinen perintö ja sen vaaliminen, käytännössä niin kutsuttu vapaussotamyytti, muotoutui sisällissodan aikana ja sen jälkeisinä vuosina. Valkoiselle historiapolitiikalle oli olennaista osoittaa sodan olleen vapaussodan, ja valkoisten keskeisten vastustajien eli punaisten taistelleen itsenäistä Suomea ja laillista hallitusta vastaan. Tässä narratiivissa punaisten rikos oli sekä juridinen että kansallinen, maanpetturuutta useassa mielessä ${ }^{10}$. Vaikka puhetta sovinnosta ja kansakunnan yhdistymisestä oli sodan jälkeen, ei tämä kattanut valkoisten monopolisoimaa muistokulttuuria ${ }^{11}$. Valkoisen perinteen, kansalaisuuden ja ideologian ytimessä oli vapaussodan uhrin velvoite, integroiva nationalismi, voittajien kuva itsestään itsenäistyneen isänmaan vaatimusten kohteena sekä tietysti viholliskuva eli "ryssäviha": Vihassa konkretisoitui keitä ei haluttu olla eikä muistuttaa. Samoihin teemoihin linkittyivät myös aseveljeyden käsitteet sekä asema ja linkittyminen länteen, jonka vastineena oli itä, aasialaisuus ja bolševismi/kommunismi. Olennaista oli Suomen asema sivistyneen Euroopan rintamalinjana uhkaa, Aasiaa vastaan ${ }^{12}$. Viholliskuvan vaaliminen sekä vapaussodassa annettu uhri ylläpitivät velvoitetta olla valmiina jatkamaan taistelua ja ponnisteluja Suomen eteen.

Valkoisten perintöä ja historiantulkintaa on mahdotonta erottaa toisistaan. Vapaussodan käsite laajeni sisällissodasta heimosotiin, vaikka nämä vapaaehtoisin käydyt sodat 1918-1922 eivät menestyneet. Käytännössä ne kuuluivat olennaisesti vapaussodan kategoriaan "pyhinä sotina" sillä ne sopivat kuvaan Suomesta sivistyneen lännen etuvartiona idän barbariaa vastaan, minkä lisäksi sodat käytiin pääasiassa myyttisessä Itä-Karjalassa. ${ }^{13}$ Monille hautausmaille nousikin vapaussodan vainajien muiston lisäksi muistomerkki heimosotureille. Samalla vuoden 1918 suojeluskunnat saivat rinnalleen toisen vaikutusvaltaisen järjestön, Akateemisen Karjala-Seuran, jonka vaiheisiin en kuitenkaan tämän katsauksen yhteydessä puutu sen tarkemmin.

Olennainen osa valkoisten perintöä olivat suojeluskunnat, niin "vapaussodan perillisinä" kuin "vapaussodan perinteen vaalijoina". Suojeluskuntien kaltaiset puolisotilaalliset joukot eivät olleet minkäänlainen erikoisuus ensimmäisen maailmansodan romuttamien imperiumien jättämissä valtatyhiöissä, joissa heikentyneen esivallan korvasi väkivalta. Suojeluskuntien asema kuitenkin vaihteli syksystä 1917 vuoden 1918 alkuun paikallisista järjestyksestä huolehtivista miliisijoukoista Senaatin julistamaksi viralliseksi armeijaksi. Keväällä 1918 ne muuttuivat käytännössä tehtävänsä täyttäneeksi järjestöksi mutta tekivät pian paluun vapaaehtoisena maanpuolustusjärjestönä, joka lopulta 1944 lakkautettiin ja jatkoi perinnetyötä säätiöiden ja järjestöjen muodossa. Tässä julkaisussa on säätiöiden ja järjestöjen synnystä ja tekemästä työstä Olli Kleemolan artikkeli "Suojeluskuntaperinnetyön organisaatiot ja ulottuvuudet 19442021".

Suojeluskuntajärjestön vaiheiden ja luonteen tarkasteluun ei tämän katsauksen yhteydessä ole tilaa tai mahdollisuuksia, vaikka niiden asema vapaussodan historian kirjoituksessa ja perinteen vaalimisessa oli olennainen. Suojeluskunnat olivat nimellisesti "puolueettomia" tai "epäpoliittisia", mutta näennäinen politiikattomuus johtui lähinnä ydinjäsenistön samanmielisyydestä. Samoin kasvava oikeistoradikalismi, 
joka yritti omia sisällissodan perinnön itselleen, näki itsensä paradoksaalisesti varsinaisesti puolueiden ulkopuolisena elementtinä, sillä isänmaallisuus ei heidän mielestään ollut poliittista. Isänmaallisuus myös oikeutti liikkeen väkivallan ja muut laittomuudet.

Todettakoon lyhyesti, ettei suojeluskunnilla ollut monopoliasemaa vapaussotaan vaan järjestö joutui osaltaan kamppailemaan vastaan tai, hampaita kiristellen, hyväksymään äärioikeiston oma vapaussodan vaaliminen. Ristiriidan tiivisti hyvin aikansa tunnetuin poliittinen pakinoitsija, nimimerkki Sasu Punanen eli Yrjö Räisänen (1888-1948) joka kirjoitti Suomen Sosialidemokraatissa (29.12.1934) punaisten hautojen kohteluista, ivaten samalla oikeiston omaa sankarivainajaintoa. "Jo eräiden vuosien ajan on porvarien kesken ollut väittelyä siitä, olisivatko ne, jotka kansalaissodassa kaatuivat valkoisella puolella, lapualaisia ja IKL:iä vai 'tavallisia valkoisia'. Erinomaisella innolla ovat lapualaiset ja ikl:t väittäneet kaikkia kansalaissodassa kaatuneita valkoisia omikseen ja senmukaisesti käyneet haudoilla juhlimassa." Sasu ehdotti, että "Porvarien olisi sovittava siitä kuinka monta prosenttia haudoissa olevista olisi lapualaisia ja ikl:iä jos eläisivät ja kuinka monta prosenttia muita." ${ }^{14}$

Sisällissodan jälkeen, ja osaksi jo sen aikana, sodan muistoja kerättiin valkoisten keskuudessa monipuolisesti aina 1930-luvulle asti. Tuolloin keräystoiminta äärioikeiston ja muiden vapaussodan kiihkeimpien vaalijoiden itse asiassa kiihtyi: Osaksi tämä oli selkeä vastareaktio yhteiskunnalliselle kehitykselle, osaksi kyseessä oli myös aito huoli siitä, että vapaussodan sukupolvi oli vanhenemassa ja muisto katoamassa. Aikaikkunaa tarkastellessa tuntuu usein unohtuvan, että sisällissodan ja talvisodan välillä ehti kulua yli 20 vuotta. Tuona aikana aikuisiksi ehti kasvaa kokonainen sukupolvi, jolla ei ollut suoraa henkilöhistoriaa sodan ajalta tai jotka olivat sen aikana lapsia. Vapaussoturiveteraanien sukupolvi oli harmaantumassa ja harvenemassa.

Aikaikkuna ulottui keräyksissä sisällissotaa pidemmälle ajalle. Vuonna 1932 alkoi ilmestyä Suomen vapaussota -lehti, jossa heti ensimmäisen numeron pääkirjoituksessa 'Itsenäisyyssodan muistot' vapaussota ulotettiin vuosikymmenien taakse: "Suomen historiassa on tuskin toista aikakautta, jonka merkitys olisi ollut niin suuri ja käänteentekevä kuin kunniakkaan oikeus- ja itsenäisyystaistelumme, joka alkoi 15p:nä helmikuuta 1899 ja päättyi 16 p:nä toukokuuta 1918." "'15 Lehden ajanrajaus itsenäisyystaistelulle on huomiota herättävä.

Lehti kuvasi tehtäväänsä: "Suomen Vapaussodan toimitus onkin ottanut korkeaksi kansalliseksi päämääräkseen näiden isänmaan historian pyhien muistojen talteen keräämisen. Se tulee palstoillaan julkaisemaan itsenäisyyssotaan ja sen esivalmisteluihin osallistuneiden kansalaisten muistelmia. Tämän tehtävän rinnalla ryhtyy se keräämään erityistä itsenäisyyssodan arkistoa, johon se toivoo jokaisen vapaussodan sotilaan, jokaisen jääkärin ja jokaisen oikeustaistelijan kirjoittavan omat kokemuksensa. Tähän tehtävään ryhtyessään luottaa lehden toimitus siihen, että se tulee saamaan osakseen Suomen kansan jakamattoman myötätunnon. Se on myös tietoinen siitä, että tällainen itsenäisyysarkisto, jonka kerääminen tosiasiallisesti kuuluisi valtiovallalle, mutta joka sen on laiminlyönyt, tulee vastaisuudessa olemaan, jos ajatus saadaan toteutetuksi, koko itsenäisyystaistelumme arvokkain muistomerkki." ${ }^{16}$ Lehti esitti selvästi, että koska Suomen valtio ei hoitanut pyhää keräystehtävää vaan laiminlöi sen, oli toimituksen Suomen kansan laajalla myötävaikutuksella ryhdyttävä tähän työhön. Merkittävää on myös, että tavoitteena ollut aineistokokonaisuus, "itsenäisyysarkisto" itsessään olisi muistomerkki. Lehti myönsi, että julkaisutyötä ja muistelua oli kyllä tehty, mutta tämä kattoi vain murto-osan olemassa olevasta aineistosta. Pääasiassa lehdessä julkaistiin sen ilmestymisaikana henkilöhistorioita, lyhyitä kertomuksia ja taistelumuistoja.

Konkreettisten muistojen keräämiseen vuonna 1935 ryhtynyt Vapaussodan Rintamamiesten Liitto julkaisi seikkaperäisen ohjeistuksen kannattajilleen. Keräyksen kohteena oli useita erilaisia aineistoja $^{17}$ : 
I Vapaussoturien elämäkerrasto

II Vapaussodan muistelmat, kertomukset, kirjeet y. m. jossa alakategorioina olivat

1) kirjeet

2) kertomukset

3) uskonnolliset muistot

4) rintama- ja sotilaslaulut

5) sanansutkautukset ja puheenparret

III Asiakirjat, kirjelmät yms.

IV Valokuvat, kartat, piirrokset

V Muistoesineet

Useat kategoriat osoittavat, että valkoisten perintö oli moniulotteinen. Tarkemmat keräysohjeet myös kertovat, miten valkoiset tässä yhteydessä käsittivät perintönsä. Selkeä ero tehtiin kategorioiden II ja III välillä. Edellinen kattoi selvästi sellaiset epäviralliset muistamisen muodot, joita nykyään pidetään muistitietona ja/tai folklorena. III kategoria taas kattoi vastineeksi viralliset muistidokumentit, asiakirjat. Keräystä ohjeistaessaan Vapaussodan rintamamiesten liitto totesi, että monesta vapaussodan vaiheesta tiedettiin edelleen hyvin vähän.

\section{Vapaussota sodan aikana: kotiinpaluujuhlat ja sankarihautajaiset}

Itse sodan aikana termiä "vapaussota", joka yhdistetään vahvasti sodan voittaneeseen valkoiseen osapuoleen, ei käytetty juurikaan ennen huhtikuuta. Sotaa nimitettiin vapaustaisteluksi aluksi lähinnä Pohjanmaalla, ja myös punaisten puolella ilmestyneissä lehdissä kuolinilmoituksissa kirjoitettiin vainajan kaatuneen "vapaustaistelussa".

Suurin osa aseita kantavista kummallakaan puolella tuskin tiesi tammikuussa 1918, mistä tarkalleen oli kysymys. Vuonna 1917 valtaosa suojeluskunnista koki suojelevansa järjestystä ja omistusoikeuksia sekä auttavansa viranomaisia lakien toimeenpanossa. Vain hyvin pieni joukko suojeluskuntalaisia näki puolustavansa itsenäisyyttä ja yrittävänsä estää venäläisiä käyttämästä niin kutsuttua poltetun maan taktiikkaa ${ }^{18}$. Vielä pitkälle tammikuussakin moni punainen ja valkoinen ajatteli edelleen olevansa pikemminkin osa järjestyksenvalvontaa kuin aktiivisesti sotaa käyvän joukko-osaston sotilas. Monille joukoille kummallakin puolella oli leimallista haluttomuus toimia kotialueensa ulkopuolella ${ }^{19}$, ja joillakin paikkakunnilla osapuolet tekivät paikallisia rauhansopimuksia. Oman erikoisuutensa sisällissodan joukoissa muodostavat jääkärit, jotka lähtivät Saksaan oppiakseen sotataitoja ja tehdäkseen Suomessa kapinan, mutta päätyivät lopulta Suomeen kukistamaan kapinaa.

Suomen sisällissota oli taisteluineen, terroreineen ja vankileireineen poikkeuksellisen verinen. Sinänsä retoriikka Suomen "puhdistamisesta" veren voimalla oli syntynyt jo ennen sotaa ${ }^{20}$. Vielä tammihelmikuussa molemmilla osapuolilla kumminkin tuomittiin lehdistössä myös oman puolen veritekoja, mutta maaliskuuhun tultaessa nämä mielipiteet vaiennettiin ja kauhutarinat, propaganda sekä huhut saivat etusijan. Sisällissodan terroria selittää olennaisesti se, että vastustajista uskoteltiin ja myös uskottiin pahin mahdollinen, jolloin myös verilöylyt tuntuivat oikeutetuilta. 
Sodan lopulla konfliktin merkitys vapaussotana korostui ja valkoiset aikalaiset kokivat, että sota oli luonut mahdollisuuden uudelle aikakaudelle, joka rakentuisi nimenomaan vapaussodan kokemuksille ${ }^{21}$. Kokemusten kerääminen ja merkitysten luominen alkoikin jo sodan loppuviikoilla niin valtakunnallisesti senaatin toimesta kuin paikallisyhteisöissä. Roselius toteaa, että kapina nähtiin esimerkiksi Loimaalla häpeätahrana, joka tuli pestä pois paikkakunnan ja maan historiasta ${ }^{22}$.

Merkittävin sisällissodan symbolisista vaiheista oli Helsingin juhlaparaati 16.5.1918, joka katsotaan sodan päättymisajankohdaksi. Paraati oli samalla vastaveto kaupungin vallanneille saksalaisille: Se korosti Suomen oman valkoisen armeijan panosta voitossa. Helsingin Sanomat otsikoi: "Suomen armeijan tulo Helsinkiin. Suurenmoisia juhlallisuuksia - Innostunut isänmaallinen mieliala. Kenraali Mannerheim ja Karjalan sankari eversti Sihvo yleisön myrskyisten suosionosoitusten esineinä”. ${ }^{23}$ Marssi oli tietoinen vastine saksalaisten kaupungissa saavuttamalle voitolle ja näiden nauttimalle kansansuosiolle.

Merkittäväksi valkoisten varhaiseksi juhlinnan muodoksi muotoutuivat rintamalta palaavien paluujuhlat. Usein sotilaita tervehdittiin kotipaikkakunnan juhlissa kiitospuhein, runoin, laululla, lahjoilla ja muilla vastaavilla huomionosoituksilla. Kaikissa pitäjissä ei juurikaan juhlittavia ollut, mutta juhlia pidettiin silti. Toukokuussa 1918 esimerkiksi pieni varsinaissuomalainen Merimasku juhli ainoaa valkoista soturiaan, Lennart Leinoa (s. 1895) joka oli osallistunut sotaan Uudenkaupungin suojeluskunnan riveissä Ahvenanmaan retkellä sekä myöhemmin Turun Rintamapataljoonan riveissä pohjoisen rintaman taisteluihin. Turun Rintamapataljoonan bistoriikin (1928) mukaan Leino oli komppaniansa kokki ${ }^{24}$. Leinolle järjestetyssä ohjelmassa hänet lausuttiin tervetulleeksi, kaksi neitiä luki runoja ja kirkkoherra esitelmöi isänmaanrakkaudesta ja sen velvoituksista. Yhteisen illallisen yhteydessä Leinolle luovutettiin 1800 markan pankkitalletus (noin $650 €)^{25}$. Sodan aikana ja sitä ennen Merimasku oli hyvin rauhallinen pitäjä. Oman ensimmäisen työväenyhdistyksensä paikkakunta sai vasta sodan aikana, punakaartia ei ollut laisinkaan ja suojeluskunta perustettiin vasta sodan jälkeen. Kylän ainut paikallinen näkyvä punainen viranomainen oli miliisi, joka ei aluksi edes ollut tietoinen nimityksestään virkaan. Punaisten riveissä menehtyi vain muutama paikkakuntalainen ${ }^{26}$.

Aapo Roselius mainitsee vastaavanlaisena pitäjänä Isänmaallisessa keväässä Loimaan, jonka sotahistoria oli tosin huomattavasti verisempi. Paikkakunnan miehistä noin joka kahdeksas, liki 500 henkeä kaatui, teloitettiin tai kuoli muissa yhteyksissä punaisina, kun taas valkoisten riveistä kaatui vain kolme. Heti keväällä 1918 näiden kolmen vapaussoturin sankarihautajaisista ja muistosta tuli valkoisen perinteenrakentamisen $\mathrm{ydin}^{27}$.

Sodan aikana sankarihautajaiset olivat molemmilla osapuolilla aluksi samankaltaiset puheineen, virrenveisuineen ja kunniavartioineen, joskin punaisten mahdollisuudet omien yksilölliseen hautaamiseen katosivat sodan loppupuolella. Suomessa sisällissodan hautajaisiin vaikutti osaltaan myös aseistuksen laatu: taistelut käytiin pääasiassa käsiasein, ja tykistöä käytettiin vain vähän. Seurauksena vainajat olivat harvoin pahoin silpoutuneita, joten kaatuneiden yksilöllinen tunnistaminen, kuljettaminen ja hautaaminen

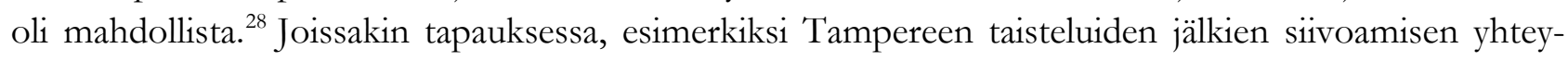
dessä pahoin silpoutuneita valkoisia päätyi punaisten joukkohautoihin. Sisällissodan "kadonneet" olivat pitkälti joukkohautoihin päätyneitä punaisia, jossain määrin toki myös valkoisia, siinä missä talvi- ja jatkosodan kadonneet olivat usein kranaattien ja pommien räjähdysten täysin tuhoamia sotilaita.

Nimenomaan sankarivainajista, isänmaan ja vapauden edestä annetusta uhrista tuli vapaussodan perinnön ydin. Sankarihautaukset muuttivat Suomessa perinteisesti perheelle ja suvulle kuuluneen juhlan koko yhteisön käsittäväksi, siis julkiseksi. Siirosen mukaan valkoiset ymmärsivät hyvin uhrin merkityksen ja tiedostivat, että hautajaisissa koetut tunteet olivat ohimeneviä, ellei niitä ylläpidettäisi kulttuuristen symbolien ja instituutioiden avulla: "Uusi valkoinen valtio oli edelleen näkymätön. Se oli personoitava ennen 
kuin se voitiin nähdä, symbolisoitava ennen kuin sitä saattoi rakastaa ja kuviteltava esiin ennen perustamistaan." Uhrit oli ikuistettava. ${ }^{29}$

Joidenkin vainajien ympärille syntyi suoranainen henkilökultti. Merkittävimpiä oli Onni Kokko (1904-1918), valkoinen lapsisotilas, joka menehtyi vain 14-vuotiaana Tampereen taisteluissa. Eteläpohjanmaalaisille taas erityisen tärkeä oli Lapuan suojeluskunnan päällikkö, "Lapuan lumiaura” Matti Laurila (vanhempi) (1865-1918), joka kaatui Länkipohjan taistelussa. Jälkikäteen Laurilaan liitettiin suoranaista

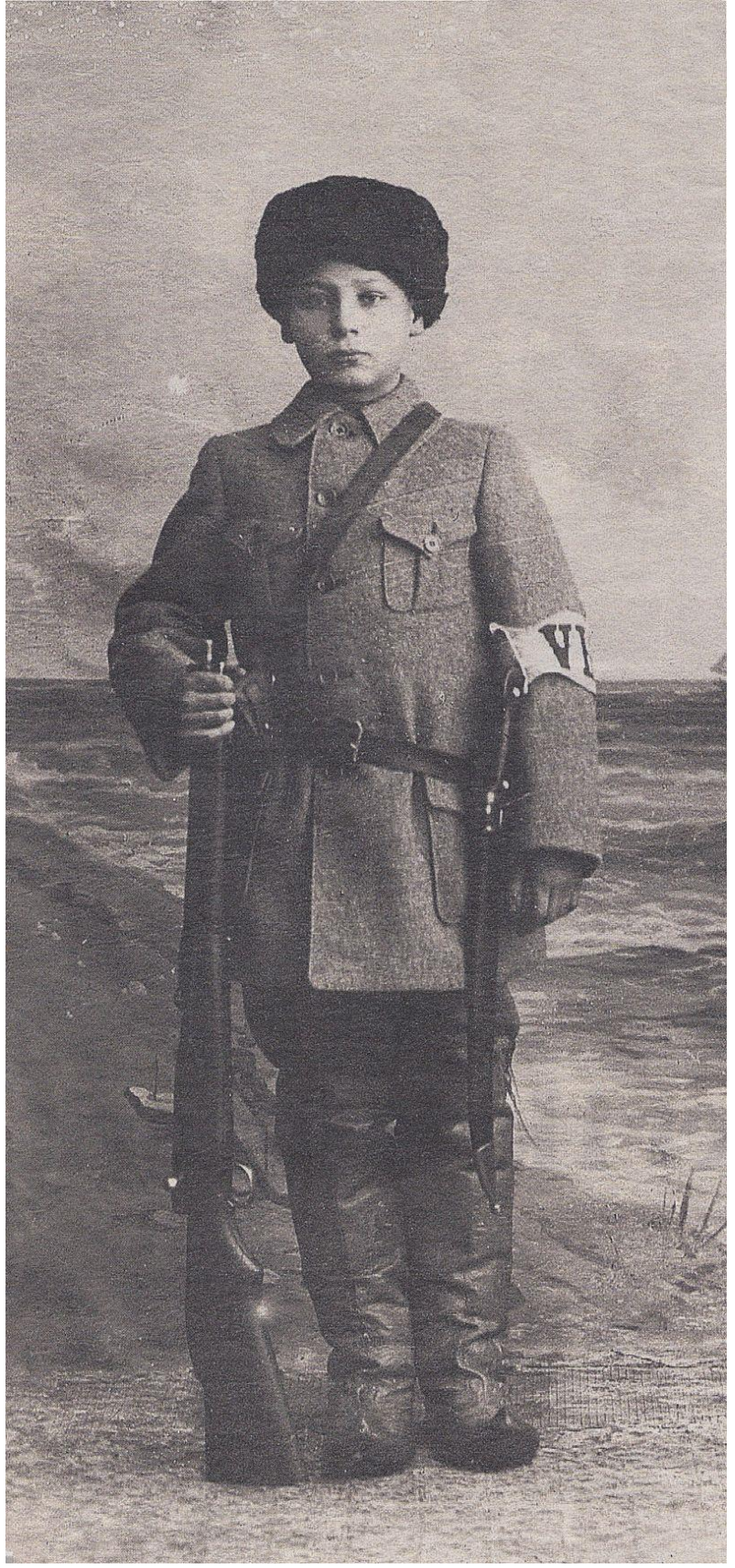

Kuva 1. Vain 14-vuotiaana Messukylässä saamiïnsa haavoibin menehtyneestä Onni Kokosta (1904-1918) tuli yksi valkoisten puolen tunnetuimmista kaatuneista. Hänen ympärilleen kebittyi suoranainen sankarivainajakultti. Kuva: Wikimedia Commons kristillistä pyhimyskulttia, kun hänen kerrottiin ennustaneen taistelun päättyvän valkoisten voittoon, mutta itse kaatuvansa sen aikana. Laurilan lähetti kertoi nähneensä Laurilan pään yllä sädekehän hänen lausuessaan profeetalliset sanat. Myös Laurilan poika Ilmari kaatui Länkipohjassa, ja perhe ikuistettiin suojeluskuntalauluun Vilppulan urbojen muistolle. Samaan kategoriaan asettui heimosotien sankari, Repolan nimismies Bobi Sivén (1889-1921), joka teki itsemurhan kuultuaan Tarton rauhansopimuksen lopputuloksesta ja nousi Akateemisen Karjala-Seuran marttyyriksi: Seuran lipun nauhoihin kätkettiin luoti, jolla Sivén oli surmannut itsensä. Alkuperäinen musta miekkalippu vihittiin 1923, ja sitä säilytetään nykyään Kansallismuseon kokoelmissa.

Sankarivainajien lisäksi punaisen terrorin uhrit saivat marttyyriaseman, ja esimerkiksi Viipurin lääninvankilassa tehdystä joukkomurhasta otetut kuvat levisivät laajalle ${ }^{30}$. Lääninvankilan murhatut olivatkin kaatuneiden valkoisten ohella olennaisia paikallisen Karjalan kansalaisliiton aloittaessa taistelun aatteista ja muistoista ${ }^{31}$. Sodan ajan viimeisten viikkojen ja sodan jälkeisten ensimmäisten kuukausien aikana sanomalehdistöä luettaessa sivuilla vyöryy vastaan punaisten terrorin uhriksi joutuneiden nimiluetteloita, kertomuksia kapinallisten hirmutöistä. Punaisten terroritöiden selostaminen ja dokumentointi oli olennaista sodan synkimmän luvun oikeuttamiselle: valkoisen terrorin. Sodan jälkeen teloituksista ja vankileireistä joko vaiettiin tai niitä vähäteltiin. Samalla myös käytännössä kiellettiin punaisilta omien vainajien muistaminen. 


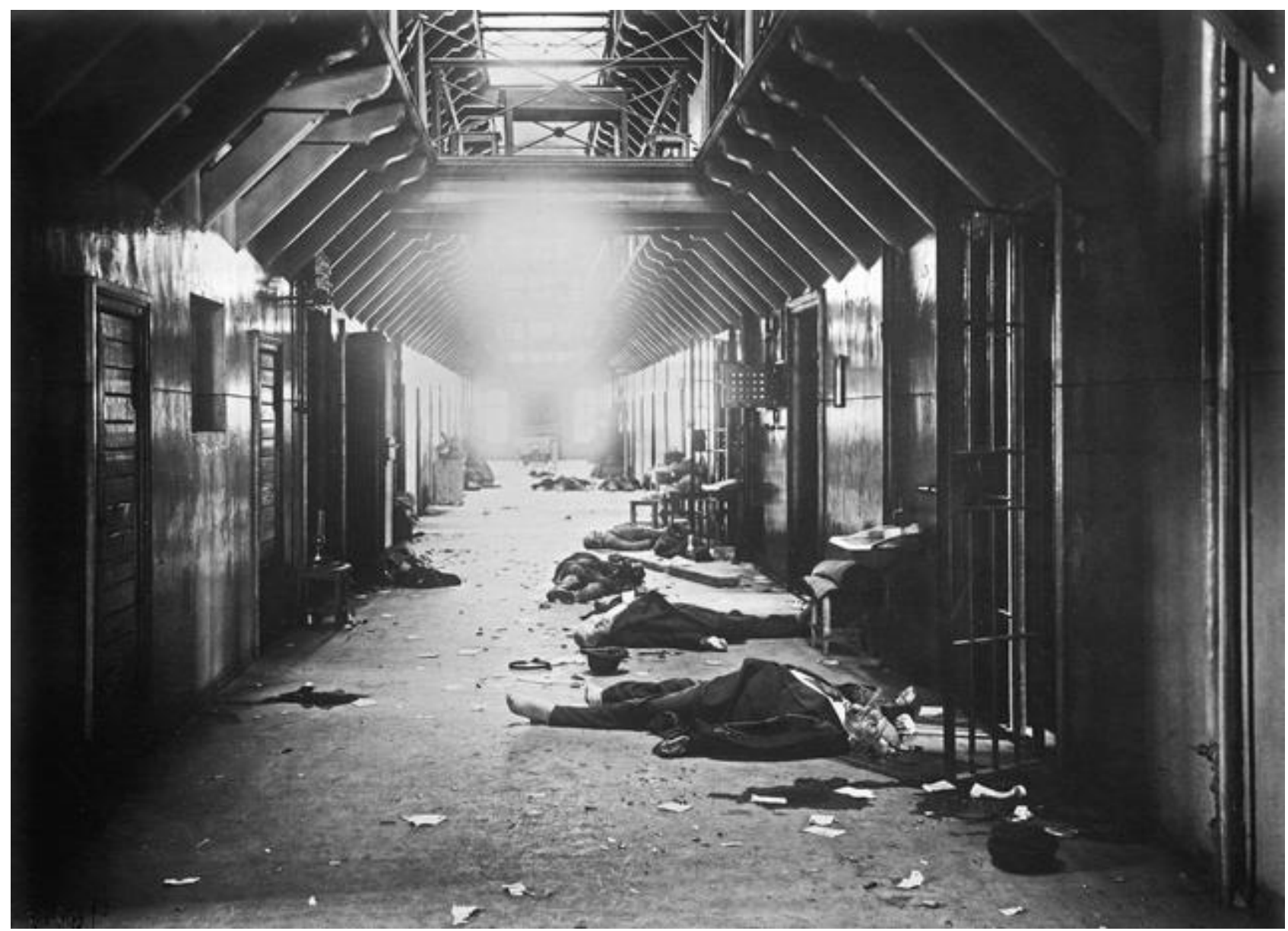

Kuva 2. Punaisten Viïpurin lääninvankilassa hubtikuussa 1918 tekemän joukkosurman ubreja esittävät valokuvat levisivät sodan lopulla ja sen päätyttyä laajalle kotimaisessa lehdistössä. Kuva: Wikimedia Commons

\section{Vapaussodan muistojuhlat: tammisunnuntaista sovinnon viikkoon}

Uusi, vapaussodasta toipuva valtio tarvitsi ja loi uusia juhlapäiviä. Sodan aikana juhlinta oli usein spontaania, mutta myös Mannerheimin 16.5.1918 Helsingissä järjestämän juhlaparaatin kaltaisia puhtaasti laskelmoituja tilaisuuksia järjestettiin. Vapaussodan perinnön jatkumon kannalta olennaista oli, ettei vuonna 1918 valkoisten voitto murskaavuudestaan huolimatta ollut vielä sinetöity, ja uhkana oli uusi punakapina ja Neuvosto-Venäjän liikkeet saattoivat uhata maata. Vuoden 1918 "lopulliset" tavoitteet, bolševikkien lyöminen ja Itä-Karjalan liittäminen Suomeen jäivät haaveiksi. Käytännön mahdollisuudet kaatuivat viimeistään presidentinvaaleissa $1919^{32}$.

Varsinainen vapaussodan juhlasuma osuikin vuoteen 1919, jolloin syntyi sekä parlamentaarisuuteen nojaava ensimmäinen tasavalta (1919-1944) että sen äärimmäinen vastareaktio äärioikeistossa. Vapaussotaan voimakkaimmin sitoutuneiden keskuudessa "työ oli jäänyt kesken". Saksaan nojaava linja romahti keisarikunnan myötä ja samalla Saksan vaikutusvalta katosi, punavankeja armahdettiin sekä vasemmisto palasi parlamentaariseen elämään ja sai vaalivoitot niin kunnallisvaaleissa kuin eduskuntavaaleissa. Lisäksi sisällissotaansa käyvä ja muun muassa Baltiaan levittäytyvä Neuvosto-Venäjä oli suuri kysymys. Vuoden 1919 juhlinta linkittyikin olennaisesti suojeluskuntien uudelleenaktivoitumiseen ja vapaussotamyytin vaalimisen syntyyn. Vuosi merkitsi valkoisen armeijan uudelleenmobilisaatiota. Moni suojeluskunta oli jatkanut toimintaansa, vaikka valtio pyrkikin ajamaan heti sodan jälkeen järjestöjä alas. Kun 
saksalaiset lähtivät joulukuussa 1918 Suomesta ja armeijan rakentaminen oli edelleen kesken, nähtiin ainoaksi vaihtoehdoksi suojeluskuntien jatkaminen. Järjestöt vahvistettiin elokuussa $1918^{33}$. Valkoisten uusi tuleminen 1919 liittyi olennaisesti myös eduskuntavaaleissa käytävään kamppailuun.

Vapaussodan muistojuhlilla oli vuonna 1919 vahvasti paikallinen luonne. Paikkakunnat saattoivat juhlia suuria merkkipäiviä kuten Pohjanmaan venäläisten aseistariisuntaa tammisunnuntaina 28.1. tai sodan päättymispäivää, Helsingin voitonparaatin päivää 16.5. Paikallisesti saatettiin juhlia esimerkiksi tammi-helmikuussa paikkakunnan suojeluskunnan perustamispäivää, ensimmäisen sankarivainajan kaatumispäivää, sankarivainajien hautajaispäivää, paikallisen venäläisvaruskunnan aseistariisumispäivää tai kevään puolella kunnan vapautumista punaisten vallan alta tai omien sotilaiden kotiinpaluupäivää. Tammisunnuntai muodostui etenkin Etelä-Pohjanmaan juhlapäiväksi. ${ }^{34}$ Juhlapäivissä oli myös erikoisia paikallisia haasteita muiden paikkakuntien vapaussotatulkinnoille: Viipurissa juhlittiin 22.1. Venäjänsaareen Viipurista vetäytyneitä suojeluskuntalaisia osoituksena siitä, että vapaussota oli Karjalankannaksella alkanut ennen Pohjanmaan tammisunnuntaita. Näiden lisäksi on huomattava, että Helsingissä sällyi Mannerheimin voitonparaatista huolimatta muistissa saksalaisten voitonpäivä 16. huhtikuuta, mitä saksalaisia komentanut kenraali von der Goltz saapui seurueineen juhlistamaan Helsinkiin viiden vuoden välein ${ }^{35}$. Suomen itsenäisyyspäivän juhlapäivä 6.12. valittiin osaksi vastapainoksi sisällissodalle: Joulukuussa se ei osunut sisällissodan ajankohtaan tammi-toukokuussa, ja näin päivä oli helpompi kokea yhteiseksi.

Eräs vapaussodan yksivuotisjuhlan suurimmista julkisista tapahtumista oli Tampereen taistelun uudelleennäytös kaupungissa huhtikuussa 1919, jossa vuoden takainen taistelu näyteltiin uudelleen manööverinä. Punaisia saivat esittää varsinaissuomalaiset suojeluskuntalaiset. Tampereen merkitys oli suuri, sillä se oli poikkeuksellisen laaja taistelu ja samalla sankarivainajia päätyi eri puolille Suomea. Melkein kaikilla kunnilla oli näin historiallinen kytkös kaupungin valtaukseen. Karjalankannaksella Raudulla oli vastaavanlainen asema ratkaisutaistelupaikkana, ja sielläkin järjestettiin taistelunäytös. Alueen asemaa korosti se seikka, että siellä taisteltiin Pietarista punaisten avuksi tulleiden venäläisjoukkojen kanssa. ${ }^{36}$

Vuoteen 1919 kuului myös valtionhoitaja Mannerheimin kierros halki maan. Kuten Aapo Roselius on Isänmaallisessa keväässä selostanut, ei Mannerheim esiintynyt tuolloin kansaa jakavien ristiriitojen sovittelijana, vaan vapaussodan kenraalina ja valkoisen Suomen edustajana ${ }^{37}$. Mannerheimin myötätuuli tyssäsi presidentinvaaleihin, joissa Suomen ensimmäiseksi presidentiksi valittiin K. J. Ståhlberg.

1920-luvulla valkoisten muistokulttuuri rakentui sankarihautojen ja muistomerkkien yhteydessä pidettävien juhlien ympärille, minkä lisäksi suojeluskuntatalot olivat tärkeitä juhlapaikkoja. Yksi suojeluskuntatalojen arkkitehtuurien olennainen piirre olikin, että niissä kuului olla juhlasali, jossa pystyttiin järjestämään iltamia ja juhlia: Samalla tiloja voitiin vuokrata juhlatilaisuuksiin tulojen saamiseksi ${ }^{38}$. Vapaussodan kymmenvuotisjuhlien yhteydessä vuonna 1928 käytiin jo keskustelua vapaussodan merkityksestä ja oikeutuksesta. Esimerkiksi Hakkapeliitta-lehdessä oli tammisunnuntaina 28.1.1928 pitkä kirjoitus aiheesta otsikolla "Miksi juhlitaan vapaussodan 10-vuotismuistoja?" Kirjoitus noudatti valkoista diskurssia, joka toisaalta pyrki sovintoon unohtamisen avulla esittäen punaiset harhaanjohdettuina, mutta ei halunnut kieltää vapaussodan historiallista merkitystä. Muut tulkinnat kuin vapaussota tyrmättiin vääränä historiantulkintana joiden kannattaminen johtaisi siihen, että "isänmaan pelastajat toiminnallaan - - asettavat heidät itsensä melkein syytettyjen penkille."39 Joissakin piireissä vuonna 1928 kyseenalaistettiin aseisiin tarttuminen itsenäisyyden turvaamiseksi, olihan bolševikkihallitus Pietarissa tunnustanut Suomen itsenäisyyden. Hakkapeliitta argumentoi, että kyseessä oli "Silmänkääntäjätemppu, jonka jälkeen sama hallitus ryhtyi Suomen 'takaisin valloitukseen', käyttäen apunaan maan omia kansalaisia antamalla käytettäväksi valtavat määrät sotavälineitä sekä myös venäläisiä joukkoja ja päällystöä. Juuri tämä sai alkamaan taistelun. Että Suomi tämän taistelun toisin päättyessä olisi jäänyt itsenäiseksi, sitä ei kukaan arvostelukykyinen ihminen tosissaan usko.” Kirjoittaja huomauttaa Venäjän tunnustaneen samalla tavalla myös Georgian 
itsenäisyyden, mutta ryhtyneen tukemaan maan kommunisteja sillä seurauksella, ettei itsenäistä Georgiaa enää ollut olemassa ${ }^{40}$.

1920-luvun lopusta alkaen vapaussotamyytin selviytymisen ja kansakunnan eheytymisen kannalta onkin olennaista, että haavojen paranemisen edellytykseksi nähtiin katkerien muistojen unobtaminen, ei niiden avoin käsittely ja tutkiminen. Tämä muun muassa suojeluskuntien edustajien julkisessa sanassa esitetty pyyntö tai vaatimus sodan ja sen perinteen käsittelystä oli yksipuolinen, mutta haluttiin ulottaa myös valkoiseen osapuoleen.

1930-luvun alkupuolella alettiin oikeistoradikalismin suitsimisen myötä etsiä entistä aktiivisemmin sovintoa. Presidentti Svinhufvud ehdotti itsenäisyyspäivän puheessaan 6.12.1933 sovinnon viikkoa sanoin "Päättäkäämme omistaa pian alkavan uuden vuoden ensimmäinen viikko keskinäisen ymmärtämyksen ja sovun edistämiselle". Viikkoa vietettiin vuodesta 1934 alkaen ja luodattiin tammikuun alussa lehdistössä laidasta laitaan. Kirjoitukset ovat hyvin kiinnostavia katsauksia suomalaisuuden sieluun. Käytännössä sovinnon viikko oli tammikuussa yhden viikon mittainen poliittinen linnarauha, jonka usein ironisen sävyinen kommentointi lehdistössä kieli Suomea yhä jakavista railoista ja useammankin lehden pakinoitsija tai muu kommentaattori totesi riitapukarien vain huilaavan. Esimerkiksi Turun Sanomat luetteli kirjoituksessa "Sovinnollisuuden viikko - tyhjä lauseparsi vaiko periaate?" litanjan riita-aiheita:

Kun monien muiden viikkeojen lisäksi on nyt tullut tällainenkin sellaista vietettiin jo päättyneen vuodenkin alussa ja kun sen viettoon sinänsä tavallaan sisältyy ajatus, että vuoden muina viikekoina voidaan vaaratta palata jokapäiväisiin tottumuksiin, kinasteluun, kissanbännän vetoon, enemmän tai vähemmän avoimeen kaikkien taisteluun kaikkia vastaan, luokkataisteluun, kielitaisteluun, kansallisuus taisteluun ja myös sïhen kansainväliseen taisteluun, joka on käynnissä monien kauniiden kylttien turvissa, taisteluun, joka on käynnissä molesta (sic), taisteluna kotimaisen työn puolesta muiden kotimaista työtä vastaan, taisteluna uusien markkinoiden puolesta toisia samojen markkinain valtaajia vastaan, kun ei sovinnon viikon ajatukseen ole yritettykään, mikeäli olemme voineet havaita, yhdistää pyrkimystä sellaisten ratkaisujen löytämiseksi, jotka lieventäisivät taistelua, joka on käynnissä taistelun arvoisista kysymykesistä, nïn ei ole ibmeteltävä, jos koko viikeko vaikuttaa jossain määrin keinotekoiselta, lirun larulta, jonkinlaiselta väsyneen mielen halulta puskea pää pensaaseen, jotta todellisuus unobtuisi. Tämä vaikutelma on nähdäksemme saanut aikaan sen, että vïme pä̈vinä, sovinnon viikon kynnykselläkin, on useissa sanomalebdissä ikäänkuin mielen nousussa ubiteltu: Viettäkää vain sovinnon viikkeoa, mutta kunhan se on sivuntettu, nïn sitten se taas alkaa; olemme valmiit pitämään yllä entistä kiivaampaa tuilta, entistä leppymättömämpää iskumieltä, entistä päättäväisempää taistelutabtoa. ${ }^{41}$

Sovintoa loi osaltaan myös Mannerheimin puhe vapaussodan 15-vuotispäivänä $1933^{42}$, jossa hän lausui, "kaikkien tulee olla mukana rakentamassa valtakuntaamme voimakkaaksi ja suureksi. Ojentakaamme sen tähden alttiiksi veljenkäsi jokaiselle, joka tahtoo tehdä työtä ja on valmis täyttämään velvollisuuden silloin, kun maata on puolustettava, se on ainoa mitä vaadimme, eikä meidän ole tarvis kysellä, missä hän oli 15 vuotta sitten."

Lapuanliikkeen perillinen, Isänmaallinen Kansanliike (IKL) vastusti sovinnon viikkoa, jonka se koki olevan suunnattu itseään vastaan. Esimerkiksi Karjalan sumnassa (2.1.1935) sovintoa ruodittiin selvin sanoin: "Me haluamme viettää joulujuhlaamme vanhojen isiltä perittyjen tapojemme mukaisesti ja me voimme viettää sovinnollisuuden viikkoakin kaikkien niiden kanssa, joiden kanssa sovinto on mahdollinen, mutta ei koskaan niiden kanssa, jotka ovat valmiit rienaamaan kansakunnan korkeimpia arvoja ja käsitteitä. Tuli ja vesi ovat sovittamattomat. Valkoinen aate ei voi koskaan viettää sovinnonjuhlaa punaisen kanssa. Niin sovittamattomia ne ovat toisilleen. Toisen täytyy tulla olemattomaksi. Molemmat ovat 
maailmankatsomuksia ja jos ne toisiinsa sekoitettaisiin, niin niistä syntyisi vain vaaleanpunainen sekotus, joka ei mitenkään valkoisen aatteen todellisia kannattajia tyydyttäisi. Punaisia ehkä, mutta silloinkin vain taktillisista syistä." ${ }^{43}$ Aika ja asenteet kuitenkin kulkivat Isänmaallista Kansanliikettä vastaan ja se teki lähinnä hallaa itselleen, kuten Hämeen Kansan 'Paikanpäältä ja syrjäseuduilta' -palstalla pohdittiin alkuvuodesta 1934 IKL:n kritisoitua arkkipiispa Ingmanin sovinnollista puhetta: ’Jos kansan enemmistöllä olisi ollut tahtoa olla sovinnollinen, ei vähemmistö halunnut sitä edes alkuunkaan. Vaikka eihän iikooälläläisten menettely toki sentään minkäänlaista tuhoa aiheuttanut kansalliselle kokonaisuudellemme. Päinvastoin mokomat riidankahinat vain kiteyttivät tasavaltalaisten rivejä yhä tiiviimmiksi ja samalla osoitti hallituspiireille, miltä suunnalta todella kunnolliset ja Suomen yhtenäisyyttä tukevat kansalaiset ovat löydettävissä. Siis hyötyä kaikesta. Jopa epäsopuisuudella pilatusta sovinnollisuuden viikostakin." ${ }^{44}$

\section{Muistojen keruu ja muistoesineet}

Vapaussodan muistojen keruu alkoi nopeasti niin valtakunnallisesti kuin paikallisesti sodan ollessa päättymäisillään tai heti sodan jälkeen. Sodan aikana jotkut komentajat esimerkiksi Karjalassa määräsivät joukkonsa jo taisteluiden yhteydessä keräämään vihollisen aseita, lippuja ja muuta esineistöä. Museoiden hoitajat keräsivät esineistöä tuoreeltaan taisteluiden jälkeen, ja esimerkiksi Tampereella Hämeen museoon saatiin Kalmin rykmentin lippu ${ }^{45}$. Viipurissa lehtori Kaarlo Soikkeli ideoi kuukausi kaupungin valtauksen jälkeen omaa laitosta, joka kokoaisi historiallisesti tärkeää aineistoa ja jonka yhteydessä toimisi museo ${ }^{46}$. Sodan museointiin oli intoa monilla paikkakunnilla.

Senaatti Vaasassa käynnisti sotamuistojen keruun kaksi viikkoa Tampereen taistelujen jälkeen saatuaan asiasta kirjallisen ehdotuksen kulttuuripersoonilta. Ehdotuksen mukaan erillisen toimikunnan piti kerätä "ainehistoa punaisten hirmuvallan menettelyn valaisemiseksi ja valokuvaamaan sen jälkiä.” Lisäksi ehdotettiin, että "hallitus antaisi laatia ja useammalle sivistyskielelle julkaista teoksen punaisesta hirmuvallasta Suomessa." Senaatti puolsi ehdotusta ja toimikunta asetettiin 17.5.1918. Sitä myötä, kun eteläinen Suomi siirtyi punaisilta valkoisten hallintaan, perustettiin keräyspiirejä, mutta monilla paikkakunnilla keruutyö oli jo aloitettu oma-aloitteisesti ${ }^{47}$. Valtionarkisto (Kansallisarkisto) määrättiin viikkoa ennen sotatoimien päättymistä keräämään sotaan liittyvää aineistoa. Hankkeen otsikko oli "Vapaussodan ja punakapinan muistot talteen", ja sitä johti arkistonhoitaja Kaarlo Blomstedt. Hän vetosi suojeluskuntiin, että kaikki materiaali, mikä auttaisi ymmärtämään tapahtumien syitä, kulkua ja seurauksia oli tarpeellista kerätä talteen. Kyse oli sodan kokeneiden velvollisuudesta tulevia sukupolvia kohtaan. Myöhemmin myös Yliopiston kirjasto (Kansalliskirjasto) ja Kansallismuseo märättiin keräystyöhön. Kansallismuseo saikin kerättyä vuoden 1918 aikana yli 400 esinettä, muun muassa Helsingin työväentalon raunioista löydetyn punakaartilaisen univormun ${ }^{48}$. Merkittävää aineistoa kertyi myös, kun valkoisen armeijan päämaja asetti huhtikuussa 1918 tutkintoasiainosaston punaisten tutkimukseksi. Vaikka keruiden tavoitteet olivat sinänsä monipuoliset, painottui niissä punaisten hirmutöiden kartoittaminen sekä punaisten ja venäläisten yhteyttä korostavien aineistojen etsiminen.

Sotamuistojen etsimisen lisäksi sodan muistoesineitä myös annettiin sotijoille, kun vapaussotaan osallistuneille sotilaille lahjoitettiin monissa kunnissa kotiinpaluujuhlien yhteydessä muistoesineitä ${ }^{49}$. Esimerkiksi Varsinais-Suomessa lietolaiset lahjoittivat sodan jälkeen valkoisten puolella taistelleille kultakellot. Kolme valkoista, jotka olivat taistelleet pohjoisrintamalla, saivat arvokkaimmat kellot ${ }^{50}$. Samoin esimerkiksi Hollolassa muistoesineitä suunniteltiin annettavaksi sotaan osallistuneille samalla kun päätettiin pystyttää hautapatsaat kuudelle vapaussodassa kaatuneelle hollolalaiselle. Asiaa edistämään asetettiin oma 
toimikunta $^{51}$. Erikoinen muistoesineryhmä ovat Winchester-kiväärin patruunoista valmistetut kynäveitset, joissa luotiin on upotettu pieni veitsi ja hylsyyn on ilmeisesti juottamalla liitetty kohokuviona leijonavaakuna ja sydän, jonka sisällä lukee "Vapaustaistelu 1918" tai muu vastaava teksti. Todennäköisesti veitsiä tehtiin sarjatuotantona ${ }^{52}$. Ei ole varmuutta, onko nämä esineet valmistettu puhdetöinä, jotain tiettyä ryhmää varten vai puhtaasti myyntitarkoituksiin. Vastaavanlaisia esineitä jaettiin myös vieraspaikkakuntalaisille, esimerkiksi Tiina Lintunen on kuvannut kultaisen luodin, jossa lukee "Vapautus-sota 1918" ja "Pomarkkulaisilta". Luoteja annettiin kunnan toimesta paikkakuntaa vapauttaneille valkoisille. Pomarkun lisäksi vastaavanlaisia esineitä jaettiin Eurassa ${ }^{53}$.

Kiinnostavasti Vapaussodan Rintamamiesten Liiton vuoden 1935 keräysohjeissa muistoesineiden kategoria on hyvin laaja: "Miltei jokaisella vapaussoturilla on hallussaan ainakin joku muistoesine vapaussodan päiviltä. Kenellä on kivääri, kenellä pistin ja kenellä taas kranaatin hylsy. Joku on saanut haltuunsa punaisten leimasimia ja rahoja, ja toisella on taas kokoelma käsivarsinauhoja ja arvomerkkejä. Mitä erilaatuisempia muistoesineitä tapaa rintamamiesten kätköistä ja suotavaa olisi, että mahdollisimman paljon niitä voitaisiin kerätä talteen. Niinikään olisi jälkeenpäin syntyneet joukko-osastojen omat merkit koottava, samoin piirustukset lipuista." ${ }^{54}$ Liiton arkistoon oli jo tätä ennen päätynyt paljon esineistöä, kuten Rintamamies-lehti selosti heinäkuussa 1933, jolloin kokoelmiin kuului muun muassa majuri von Essenin Suomen sodassa 1808 käyttämä satula, vapaussodassa käytettyjä sapeleita, pistooleja ja kiväärejä, kunniamerkkikokoelma, joukko-osastojen sotilasmerkkejä sekä "eräitä punaisten maksuosoituksia" ${ }^{55}$. Sodan muistoesineet olivat siis laaja-alaisuudessaan sangen sekava kategoria, johon kuului niin sotasaalis, sodanajan omat symbolit, aseistus kuin vanhempien aikakausien esineistö. On toisaalta todennäköistä, että Suomen sodan aikainen satula pikemminkin päätyi arkiston kokoelmiin kuin erikseen pyydettiin sinne. Käytännössä kuitenkin mikä tahansa esine saattaa olla vuoden 1918 esine, ja lähes mikä tahansa saatettiin myös linkittää Suomen vapaussotaan sotahistoriallisuutensa välityksellä. Suomessa kiertää edelleen monessa perheessä perintönä ase, jonka esi-isä sai vuonna 1918.

Oman erikoisuutensa sisällissodan muistokulttuuriin tuovat sodan ajan valokuvat. Sodan aikana ei kummallakaan osapuolella (saksalaisia lukuun ottamatta) ollut varsinaista tiedotuskomppanioiden tai muiden propagandayksiköiden kaltaista erikoistunutta dokumenttimateriaalia toimittavaa laitosta. Molemmat osapuolet julkaisivat kyllä kuvitettuja propagandajulkaisuja, mutta ammattimainen propagandatoiminta oli niistä kaukana ja kuvitus oli lähinnä yksityisten ottamia kuvia. Sodan aikana kuvaamista yritettiin kontrolloida, ja esimerkiksi Tampereen komendantti Gustaf Finne ilmoitti tuoreeltaan kaupungin valtauksen jälkeen "valokuvaajille", että sodan vaurioiden valokuvaaminen joko ulkona tai sisällä Tampereen kaupungissa ja sen alueella kiellettiin muilta paitsi toimitusjohtaja Isak Räsäsen valtuuttamilta valokuvaajilta. Muuten "Kaikki jo otetut valokuvat on tuotava rakennusmestari H. Tiitolan konttoriin Kirkkokatu 5. ${ }^{, 56}$ Heti sodan jälkeen valokuvia yritettiin kerätä muun muassa kansakoulupiireittäin, ja esimerkiksi Opettajain lehti kehotti kouluja valokuvien keruuseen marraskuussa $1918^{57}$. 


\section{Valo- \\ kuvaajille.}

Scdan tuottamien vaurioiden valokuvaaminen, joko ulkona tai sisällä Tampereea kaupung'ssa ja sen alueella hielletāân kaikilta paitsi toimitusjohtaja lsak Rāsāsen valtustamitta. Kaikisi jo otetut valokuvat ovat tuotava Rakennusmest: ri $\mathrm{H}$. Tiitolan kontoriia Kirkkokalu 5.

Tampereen kaupungin komen$d * n t i$ ko ttoor. sa 6. 4. 1918.

\section{Gustå Aduli Finne.}

Kuva 3. Sisällissodan ajan valokuvat olivat pääasiassa y kityisten ottamia valokuvia. Sodan aikeana kuvaamista pyrittiin monin paikoin rajoittamaan käskyin ja objein, kuten Tampereen Sanomissa kaupungin taisteluiden jälkeen 9. bubtikuuta annetussa käskyssä. Sodan jälkeen valokuvia pyydettiin lähettämään arkistoibin, julkaistaviin historiikekeihin ja lehtiin useissa keräyksissä. Kuva: Tampereen Sanomat 9.4.1918

Poseerauskuvat, kuten suojeluskuntalaisten yhteiskuvat ennen rintamalle lähtöä tai taisteluiden jälkeen, on todennäköisesti tarkoitettu alun perin vain pienen piirin käyttöön, eivät julkisen muistelun välineiksi. Joidenkin henkilöiden, kuten Mannerheimin tai Tampereella kuolettavasti haavoittuneen Onni Kokon ympärille luotiin myös kuvien avulla kulttia. Erikoisen ja Kleemolan mukaan huomattavan eron esimerkiksi saksalaiseen kuvien käyttökulttuuriin muodostavat siekailemattomat ruumiskuvat. Raaoissa kuvissa esitetään punaisten vainajien lisäksi myös valkoisia kaatuneita, ja muissakin yhteyksissä kuin hoidettuina sankarivainajina. ${ }^{62}$

Kahdesta teoksesta Suomen vapaussodan kwvat on huomattavasti jyrkempi punaisia kohtaan kuin myöhempi kansanpainos, Vapaussodan kuvahistoria. Erikoisen kuvateoksista tekee se, että niiden aineisto saatiin valtiollisten propagandakoneistojen arkistojen sijaan yksityisiltä tahoilta. Vihollisia, punaisia esittävät kuvat ovat pääasiassa punaisten itsensä ottamia poseerauskuvia, jotka Suomen vapaussodan kuvissa on ryhmitelty kavalkadiksi kuvatekstin "Punakaartilaistyyppejä" alle. Mukana on myös valokuva punaisista sairaanhoitajattarista. Kleemolan mukaan kuvien ryhmittelyssä on kyse toiseuttamiskeinosta, tyyppikuvauksesta, joka oli käytössä jo kolonialismin ja löytöretkien aikakaudella. Yksilölliset punaisten kuvat 
muuttuivat valkoisessa historian käsittelyssä "punaisuuden edustajiksi" ${ }^{63}$. Muuten vihollista ja tämän toimintaa esittävien kuvien ja valkoisia esittävien kuvien ryhmittelyllä luodaan Kleemolan mukaan vastakohtia epäjärjestyksen ja järjestyksen, tuhon ja sällyttämisen välillä. Tuhotun Karkun kirkon vastineena on valokuva valkoisista vannomassa sotilasvalaa Ilmajoen kirkossa, ja turmellun Louhisaaren kartanon vastinparina on kuva valkoisista harjoituksissa Vaasassa Topeliuksen patsaan luona ${ }^{64}$. Vapaussodan kuvahistoria on punaisten kuvauksessa huomattavasti maltillisempi esittäen nämä lähinnä johtajiensa harhaanjohtamina uhreina ${ }^{65}$.

\section{Valkoisen musiikin vaiheet}

Oman erikoisuutensa valkoisten perinnössä muodostaa musiikki, jota professori Vesa Kurkela on käsitellyt Sisällissodan pikk.kuättiläisessä sisällissodan musiikkia käsittelevässä artikkelissaan ${ }^{66}$. Musiikin kohdalla on huomattava, että tutkimuksellisesti mielenkiinto on kohdistunut punaisiin ja kahtiajako on selkeä. Siinä missä valkoisten musiikkiin kuuluvat sotaisat klassiset marssilaulut, yhdistetään punaisiin lähinnä vanhat työväenlaulut tai vankileirien kurjuutta kuvaavat kappaleet, vaikka sotaisampaakin musiikkia syntyi. Jääkärimarssi, Kunlaruiskulaulu, Vapaussoturin valloituslaulu tai Vöyrin marssi yhdistetään olennaisesti vuoteen 1918, samoin Jääkärimarssin säveltäjän Jean Sibeliuksen vaiheet tai jokseenkin hämärissä olosuhteissa menehtynyt Toivo Kuula. Valkoisten musiikkia on kuitenkin tutkittu ilmeisen vähän, siinä missä punaisten eli hävinneiden musiikki on saanut enemmän huomiota osakseen. Osasyynä tähän on se, että punaisten musiikkia levytettiin ensimmäisen kerran etenkin Pohjois-Amerikassa ${ }^{67}$ ja näin musiikki asettui ja asettuu osaksi suomalaista Amerikan siirtolaisuuden tutkimusta. Kappaleita on talletettu myös erilaisissa keruissa, ja kuuluisan Love Recordsin tuotantoon, johon kuului olennaisesti vasemmistolainen musiikki, on kiinnitetty paljon huomiota.

Musiikki oli osa valkoisen Suomen perintöä heti sodan jälkeen, mutta erityiseen suosioon nousi Sibeliuksen Jä̈kärimarssi muiden kappaleiden ollessa lähinnä uudelleensanoituksia vanhoihin sävellyksiin. Toimittaja Väinö Leisio (1897-1958) tiivisti Suojeluskuntien Hakkapeliitta -lehdessä vuonna 1934 sodan annin musiikille: "Vapaussotamme kesti suhteellisen vähän aikaa ennättääkseen suoranaisesti rintamille tarjota - Jääkärimarssin lisäksi, joka jo sellaisenaankin oli riittävä panos silloin päätökseen saatetun historiallisen vaiheemme kuvaajaksi sanoin ja sävelin - juuri muuta kuin uusia sanoja vanhoihin säveliin sekä arkkiveisunluontoisia joukkolauluja, kuten 'Suojeluskunnat Suomenmaassa järjestystä’ vaatii’ y.m.’. Kerrottakoon kiinnostavana sivuseikkana, että varsinaisesti Leision artikkelin aiheena oli Lahdesta sodan loppuvaiheella tehty "harvinainen löytö vapaussodan ajoilta", nimittäin punaisten puolella toimineen porilaisen kapellimestarin Emil Hällströmin (1864-1918) ${ }^{68}$ sävellys Porin Puna-kaartin marssi. Kirjoittaja luovutti hallussaan olleen partituurin kokonaisuudessaan Sotamuseolle. Leisio myös muisteli omalla rintamaosuudellaan vastapuolen tervehtineen valkoisia pääsiäisaamuna laulamalla suomalaisten kansanlaulujen sovitelmaa. "Myönnettäköön, että se oli psykologisesti oikein harkittu tuona herkkänä juhlapäivänä korostamaan vapaustaisteluumme liittynyttä veljessodan surkeutta" ${ }^{\prime 9}$

Sotaisa Vöyrin marssi jäi vähemmälle huomiolle ja ilmeisesti pienen piirin käyttöön: Esimerkiksi "Vöyrin kaartilaiset" järjestivät Savonlinnassa jälleennäkemisjuhlan 27.-28.7.1918, lopettaen kokouksensa Vöyrin marssilla. Muuten laulua ei nähtävästi laulettu juurikaan sodan jälkeisissä tilaisuuksissa ${ }^{70}$. Eino Leino julkaisi oman Vöyrin marssi -nimisen runon julkaisussa Vöyrin sotakoulu (1918), jonka Leevi Madetoja sävelsi. Varsinaisen Vöyrin marssin sanoittajaa ei ole tiedossa. Vesa Kurkelan mukaan monet sisällissodan aikana syntyneet hirtehishuumoria sisältävät ja kuplettityyliset valkoisten puolen kappaleet unohdettiin tarkoituksella, sillä ne eivät sopineet arvokkaaseen valkoisen voiton juhlintaan ${ }^{71}$. Sen sijaan esille 
nostettiin "patsastelulauluja", jotka korostivat uhrimieltä ja armeijan taistelutahtoa. Näiden säveltämiseen osallistui Suomen eturivin muusikkoja. Robert Kajanus sävelsi Surusoiton ja Sankarilaulun, joista jälkimmäisen omisti Mannerheimille. Selim Palmgren sävelsi Mannerheim-marssin ja Valkokaartin marssin, Ilmari Hannikainen niin ikään Valkokaartin marssin, Heino Kaski Karjalan marssin, Bengt Carlson Valkoisten laulun, Leevi Madetoja Vapauden marssin, Toivo Kuula Suojeluskuntien marssin ja Oskar Merikanto Rautatieläisten suojeluskuntamarssin. Hyvin suosituksi nousi etenkin Etelä-Pohjanmaalla Heikki Klemetin Vilppulan urhojen muistolle ${ }^{72}$. Suosituimmaksi nousi ja jäi kuitenkin Sibeliuksen Jääkärimarssi.

Vapaussodan Rintamamiesten Liitto ohjeisti vuonna 1935 laulujen keruuta omana alakategorianaan: "Kaikissa joukko-osastoissa laulettiin useita vapaussotaa ja sen tapahtumia kuvaavia lauluja. Usein nämä laulut olivat samoja, mutta varmaankin monilla joukoilla oli omiakin laulujaan, sellaisia, jotka joko sisällyksensä tai muiden seikkojen takia ovat jääneet tuntemattomiksi. Samat laulut taas eri joukoissa vaihtuivat sanoiltaan usein hyvinkin huomattavasti. Keräystyö olisi ulotettava myös näihin lauluihin ja niiden sävelmiin. Niitä talteen ottaessa olisi muistiin merkittävä joukko-osasto, jonka keskuudessa laulu on syntynyt, sen mahdollinen tai mahdolliset sepittäjät, säveltäjä y.m. tarpeelliset tiedot."73

Valkoisen historian näkemyksiä yritettiin joidenkin (hatarien) tietojen mukaan liittää musiikissa niinkin erikoisiin yhteyksiin kuin jouluperinteisiin kuuluviin Tiernapoikiin. Keskiaikaista mysteerinäytelmää oli jo 1800-luvulla muokattu kiittämällä Venäjän keisari Aleksanteri I:ä. Suomessa ei itsenäisyyden myötä Venäjän hallitsijaa enää käynytkään kiittäminen vaan tilalle haettiin sopivampaa sankaria. Esimerkiksi Tauno Kokko (1899-1983) ehdotti sanomalehti Kalevan artikkelin mukaan ${ }^{74}$ vuonna 1941 tilalla laulettavan "Pohjolan sotasankari Mannerheimistä", mutta joidenkin tietojen mukaan muutosta ehdotettiin jo sotien välisenä aikana. Tästä ei kuitenkaan ole ainuttakaan mainintaa sisällissodan jälkeisen ajan lehdistössä. Herääkin kysymys, onko väite Mannerheimin tuomisesta Tiernapoikiin puhdas nykytarina eli urbaanilegenda. Ainakin mahdollinen hanke jäi hyvin pienen piirin puuhasteluksi, eikä Aleksanterista laulamista julkisesti sodan jälkeen vastustettu Pohjanmaalla, vapaussodan- ja tiernapoikaperinteen ydinalueella. Korkeintaan keisarille hymähdeltiin.

Valkoiset laulut eivät kadonneet minnekään ja säilyivät olennaisilta osin armeijan soittokuntien ohjelmistossa. Scandia-Musiikki Oy tuotti vuonna 1969 levyn Talonpoikaisarmeijan lauluja ${ }^{75}$. Oman kummallisuutensa levyyn tuo se, että yksi laulajista oli Reijo Frank (1931-2017), joka oli tunnettu etenkin työväenlaulujen tulkitsijana. Reijo Frank osallistui samaan aikaan myös levyihin Työväen lauluja ja Työväen lauluja 2. Käytännössä valkoisen Suomen marssilaulut tunnustettiin jo yhteiseksi musiikiksi. Suomen Kuvalehti (30/1970) kiitti Scandia-Musiikki Oy:tä, kun se oli ottanut "urakakseen melkoisen kulttuurityön suomalaisen musiikin alueella". Talonpoikaisarmeijan laulujen sekä työnväenliikkeen marssien ja laulujen lisäksi yhtiö oli julkaissut talvi- ja jatkosodan musiikkia käsittävän levyn Sota-ajan iskelmiǟ7 . Tämä tapahtui 20 vuotta ennen uusisänmaallista käännettä. Stump-lehti kiitteli Talonpoikaisarmeijan lauluja sanoin: 'Työväen laulujen tavoin kuuluu tämä Talonpoikaisarmeijan lauluja sisältävä albumi merkittäviin levyihin nimenomaan kansankulttuurin kannalta. Sekä punaisten että valkoistenhan laulut ovat olleet 'kiellettyjä' viime aikoihin asti. Vieläkin kuulee sanottavan ko. laulujen herättävän pahaa verta puolin jos toisin.’’77 Jo vuosina 1969-1970 valkoista ja punaista musiikkia nivottiin yhteen yhteisen suomalaisen kulttuuriperinnön alle.

Uusisänmaallisuuden vanavedessä 1990-luvulla julkaistiin levyt Isänmaan laulija: Songs of the Fatherland (1992), Muistoja Pobjolasta: Valkoisen Suomen lauluja (1997) sekä vuonna 2011 kokoelma Sininen ja valkoinen: isänmaan marsseja ja lauluja, joka sisälsi vuosina 1958-1998 tehtyjä levytyksiä. Uusisänmaallisuuden hengen tutkimusmielessä on mielenkiintoista, että käyttäjä TheAlmightyPiePowerin Youtubeen 11.4.2010 lataamaan Vöyrin marssin suosituimpaan videoversioon ${ }^{78}$ on kuvitukseksi liitetty pääasiassa kuvaotoksia Pekka Parikan vuonna 1989 valmistuneesta Talvisota-elokuvasta. Näin kiinteästi sisällissotaan ja samalla 
"vaikeaan" sotaan liittyvä marssi liitetään osaksi "hyväksyttävämpää" sotaa. Loogisempi linkki marssiin syntyy tietenkin siitä, että elokuva kuvaa pohjanmaalaisten sotilaiden vaiheita.

\section{Muistomerkkien tulva}

Sisällissotaa seurasi käytännössä teollinen muistomerkkien tehtailu eri puolille Suomea, kun muutamassa vuodessa eri puolille Suomea kohosi kaikkiaan neljälle sadalle paikkakunnalle sodan muistopatsaita.

Riitta Kormano on analysoinut valkoisten muistomerkkien muotokieltä väitöskirjassaan Sotamuistomerkki Suomessa: voiton ja tappion modaalista sovittelua (2014). Hän toteaa, että "ensimmäisen tasavallan aika oli maskuliinisten aiheiden kulta-aikaa". Sankarihaudat saivat seurakseen suojeluskuntalaisen pukuun sonnustautuneet sotilaskuvat etenkin maaseudun valkoisten sankarihaudoille, kun taas kaupungeissa pitäydyttiin klassismin ideaaleihin. Kormanon mukaan tilanne saattoi kertoa kaupunkien ja maaseudun muistomerkkitoimikuntien jäsenten koulutustaustojen eroista tai viitata erilaisiin yhteisöllisiin ja paikallisiin tarpeisiin. Kaupungeissa keskityttiin yleensä voiton tai vapauden idean välittämiseen herooisella itsevarmuudella, kun taas maalaiskunnissa kuvasto ilmensi harrasta, isänmaan tehtäviin valmiin sotilaan mallikuvaa. Molemmissa tapauksissa muistomerkit korostivat kansallista imagonrakennusta valtiollisen olemassaolon perustana. Kormano huomauttaa, että paikallisvärin korostamisesta tuli leimallisesti vasta toisen maailmansodan jälkeinen ilmiö. Sankarihaudoista tuli "kotiseudun mullan" paikallismerkkejä ja aseveljeyden lunastuspaikkoja, mitä painotettiin maakunnallisilla ja paikallisuuteen liittyvillä viitteillä. ${ }^{79}$

Tässä mielessä suojeluskuntien asema muistomerkkikulttuurissa on olennainen: Järjestö oli valtakunnallinen, mutta sen paikallinen vaikutusvalta oli luja. Juuri suojeluskunnat yleensä käynnistivät patsashankkeet ja keräsivät niihin varoja ja etenkin vuoden 1919 muistojuhlia hyödynnettiin rahankeruussa. Paikallisuus ei kuitenkaan näkynyt muistomerkkien erityispiirteenä. Osaksi tämä johtui varmasti siitä, että muistopatsas haluttiin mieluiten nopeasti, taloudellisten raamien puitteissa (eli halvalla) sekä varmuudella. Merkittäväksi tekijäksi nousi hankolainen Granit Ab ja sen muotoilija Ilmari Wirkkala, kuten Aapo Roselius on selostanut Isänmaallisessa keväässä. Ensimmäisen vapaussodan muistomerkkitilauksen yhtiö sai jo kesäkuussa 1918 ja niitä tuli jatkossa runsaasti lisää. Muistomerkkien pystytys oli usein spontaania paikallista toimintaa, mutta senaatti halusi puuttua muistomerkkeihin perustamalla Valtion kuvaamataidelautakunnan, joka tarkasteli muistomerkkihankkeita. Tavoitteena oli saada aikaiseksi taiteellisesti mahdollisimman korkeatasoisia muistomerkkejä. Paikallisuus kuitenkin löi valtakunnallisen suunnittelun, ja paikallisella tasolla korostui merkin pystyttämisen nopeus. Kilpailuissa tärkein tekijä oli Granit, jonka suunnittelija Wirkkala perehtyi tehtäväänsä huolella, suunnitellen valmiita malleja ja luonnoksia, joten tilaajan ei välttämättä tarvinnut maksaa erikseen muistomerkin suunnitelmasta. Merkit olivat pääasiassa turvallisia ja klassisia, eivätkä juurikaan taiteellisesti kokeellisia. Wirkkala kannatti yksinkertaisuutta ja inhosi esimerkiksi vuoden 1870 Saksan ja Ranskan välisen sodan muistomerkkejä ${ }^{80}$.

Ensimmäisen tasavallan aikana muistomerkkejä pystytettiin äskettäisten sankareiden lisäksi vanhemmille esimerkeille, kuten nuijasodan taisteluiden paikoille. ${ }^{81}$ Etenkin Pohjanmaalla, missä vapaussodan vaaliminen oli erityisen tärkeää, pystytettiin sodan jälkeen useita muistomerkkejä menneisyyden taisteluille ja taistelijoille. Samalla pyrittiin myös keräämään tietoja vanhemmista sotamuistomerkeistä, joita oli pystytetty Suomeen jo 1800-luvulla.

Patsaita kohosi niin nopeaa tahtia, että monen taustavaikuttajat ja muut tiedot uhkasivat jäädä unholaan. Vapaussodan Rintamamiesten Liitto keräsi vuonna 1935 tietoja myös näistä, koska keräystyön yhteydessä nähtiin voitavan "vähällä vaivalla hankkia tiedot kaikista näistä muistomerkeistä". Keräyksessä toivottiin valokuvia muistomerkeistä, niiden paljastustilaisuuksista, kunnianosoituksista niiden luona ja 
muista vastaavista tapahtumista sekä selvitys patsaiden ja muistomerkkien rakentamisesta, rakentajista, lahjoittajista, valmistumisajasta, paljastustilaisuudesta ja muita vastaavia tietoja ${ }^{82}$.

Punaiset saivat pystyttää vain muutaman muistomerkin, jotka joko vandalisoitiin, oikeuskäsittelyn jälkeen purettiin tai niihin puututtiin muilla keinoilla. Turun Uudella hautausmaalla seisoo edelleen punaisten veljeshaudalle vapun alla 27.4.1921 yhdessä yössä pystytetty jykevä graniittipaasi, josta tosin poistettiin melkein heti punainen lippu sekä kupeissa olleet kilvet. Riihimäellä Mäntymäelle vuonna 1923 pystytetty muistomerkki turmeltiin ja muistomerkin pystyttäjät haastettiin oikeuteen "patsaan luvattomasta pystyttämisestä" ja "rikosten ylistämisestä". Kiinnostavaa sinänsä, kihlakunnanoikeus ei lokakuussa 1923 pitänyt patsaan pystyttämistä rikoksena, vaan tuomio annettiin "lausutuilla sanoilla ylistetystä valtiopetoksesta." ${ }^{83}$ Valkoisen Suomen perinnön kannalta olennaista oli, ettei punaisten muistomerkkien hävittämistä "vapaaehtoisten" eli usein paikallisten suojeluskuntalaisten toimesta varsinaisesti hyväksytty vaan poistamisen haluttiin olevan viranomaistoimenpide. Omavaltaisesti punaisten muistomerkkejä hävittävät yksityishenkilöt piti asettaa syytteeseen ${ }^{84}$, mutta valtaosassa tapauksista poliisi ei tutkinut tuhoamisia tosissaan ja rikokset vanhenivat. Hämeenlinnaan vuonna 1924 joukkohaudalle pystytetty muistomerkki kaadettiin nimenomaan viranomaisten toimesta, vaikka kirkkoherra oli antanut sen pystyttämiselle luvan. Muistomerkkien kieltämisen taustalla oli pelko siitä, että niistä muodostuisi äärivasemmiston kulttipaikkoja. Samalla niiden koettiin loukkaavan vapaussodan perintöä. Punaisten sallittiin tietyissä yhteyksissä käydä vainajien haudoilla, mikäli sukulaisuus oli todistettavissa: Siinä missä valkoisten sankarihautajaiset ja muistaminen muotoutuivat yksityisestä julkiseksi, tehtiin punaisten kohdalla juuri päinvastoin. Vaatimus sukulaisuudesta oli kuitenkin mieletön, koska joukkohaudoissa oli esimerkiksi Hämeenlinnassa useita tuhansia vainajia.

Suomessa vallitsi vuodesta 1918 aina 1920-luvulle asti oikea patsastaistelun kulttuuri. Yleisellä ja yhtäläisellä äänioikeudella toteutuneissa ensimmäisissä kunnallisvaaleissa vasemmisto sai huomattavasti paikkoja kunnallisvaltuustoissa ja pystyi jarruttamaan tai estämään valkoisten muistomerkkihankkeita. Merkittävä kamppailu käytiin Tampereen vapaudenpatsaasta, jonka pystyttämistä Tampereen kaupunginvaltuuston vasemmistoenemmistö vaati vuonna 1919 keskeytettäväksi vetoamalla kaupungin taloudelliseen tilanteeseen. Patsas kuitenkin pystytettiin, jolloin alettiin vaatia sen purkamista. Valtuusto teki päätöksen patsaan tuhoamisesta huhtikuussa 1922 mikä aloitti uhkailujen (muun muassa Lapuan suojeluskunta esitti ukaaseja), taloudellisen kiistelyn ja valituksien kierteen, joka päättyi vasta syyskuussa 1923. Maistraatti oli toukokuussa 1922 kieltäytynyt toteuttamasta valtuuston päätöstä vedoten muinaismuistolakiin, ja lopulta 2.4.1883 annettu laki suojeli muistomerkin muinaismuistona. ${ }^{85}$

On toisaalta huomattava, että taisteluita patsaista käytiin muillakin akseleilla kuin valkoinen/punainen ja isänmaallisuutta, tai sen puuttumista, käytettiin myös näissä yhteyksissä argumentteina. Esimerkiksi Vaasan hovioikeuden täyttäessä 150 vuotta kuningas Kustaa III:n muistomerkin pystyttämistä Vaasaan vuonna 1926 vastustettiin "kiihkoruotsikkojen" hankkeena. Paikallislehti Vaasa otsikoi hankkeesta 30.4.1926 rubriikilla "Itäruotsalaisuuden julkeus kukassaan" ivaten kirjoituksessa, ettei kuningas ollut tehnyt kummempia ansioita hovioikeuden eteen kuin nimensä kirjoittamisen virkapaperiin. Huomionarvoisena seikkana Vaasa piti patsashanketta "- - kiihkoruotsalaisen, Ruotsin valtakuntaa kaikessa palvovan klikin keskuudessa, josta muutkin Vaasan 'itäruotsalaisten' poliittiset ja epäisänmaalliset yritykset ja aikaansaannokset ovat peräisin." 86

Muistomerkkikulttuurin myötä- ja vastatuulet konkretisoituivat hyvin Hangon vapaudenpatsaassa, joka oli pystytetty 16.5.1921 kaupunkiin maihinnousseiden saksalaisten muistolle. Kiveen oli tuolloin kuvattu saksalainen sotilas, jonka tunnisti hyvin kypärästä, sekä kaksi Suomen leijonaa. Koska Suomessa oli kyseisenä ajankohtana lukuisia paikallisia ja valtakunnallisia muistomerkkihankkeita oli patsaan pystyttämiseen vaikeuksia kerätä rahaa. Patsashanke joutui vastatuuleen myös sen vuoksi, että sen päästyä 
käyntiin Saksa oli hävinnyt sodan ja samalla suomalaisjoukkojen panosta sisällissodassa haluttiin entisestään korostaa ${ }^{87}$. Lopulta muistomerkki saatiin aikaiseksi ja siihen ikuistettiin sanat "Saksalaiset joukot nousivat maihin Hangossa huhtikuun 3 päivänä 1918 auttamaan maatamme sen taistelussa vapautemme puolesta. Vielä myöhäisiin aikoihin todistakoon tämä kivi kiitollisuuttamme”. Ikuistaminen tosin jäi väliaikaiseksi. Talvisodan jälkeen Hanko vuokrattiin Neuvostoliitolle sotilastukikohdaksi, jolloin muistomerkki purettiin. Kun Hanko jatkosodan aikana päätyi taas suomalaiskäsiin, löytyivät muistomerkin osat säilytettyinä mutta vaurioituneina. Muistomerkki pystytettiin uudelleen vuonna 1943 ja varustettiin lisäkilvellä, johon ikuistettiin sanat: "Vihollinen häpäisi ja tärveli kiven vv. 1940-1941. Se pystytettiin uudel-

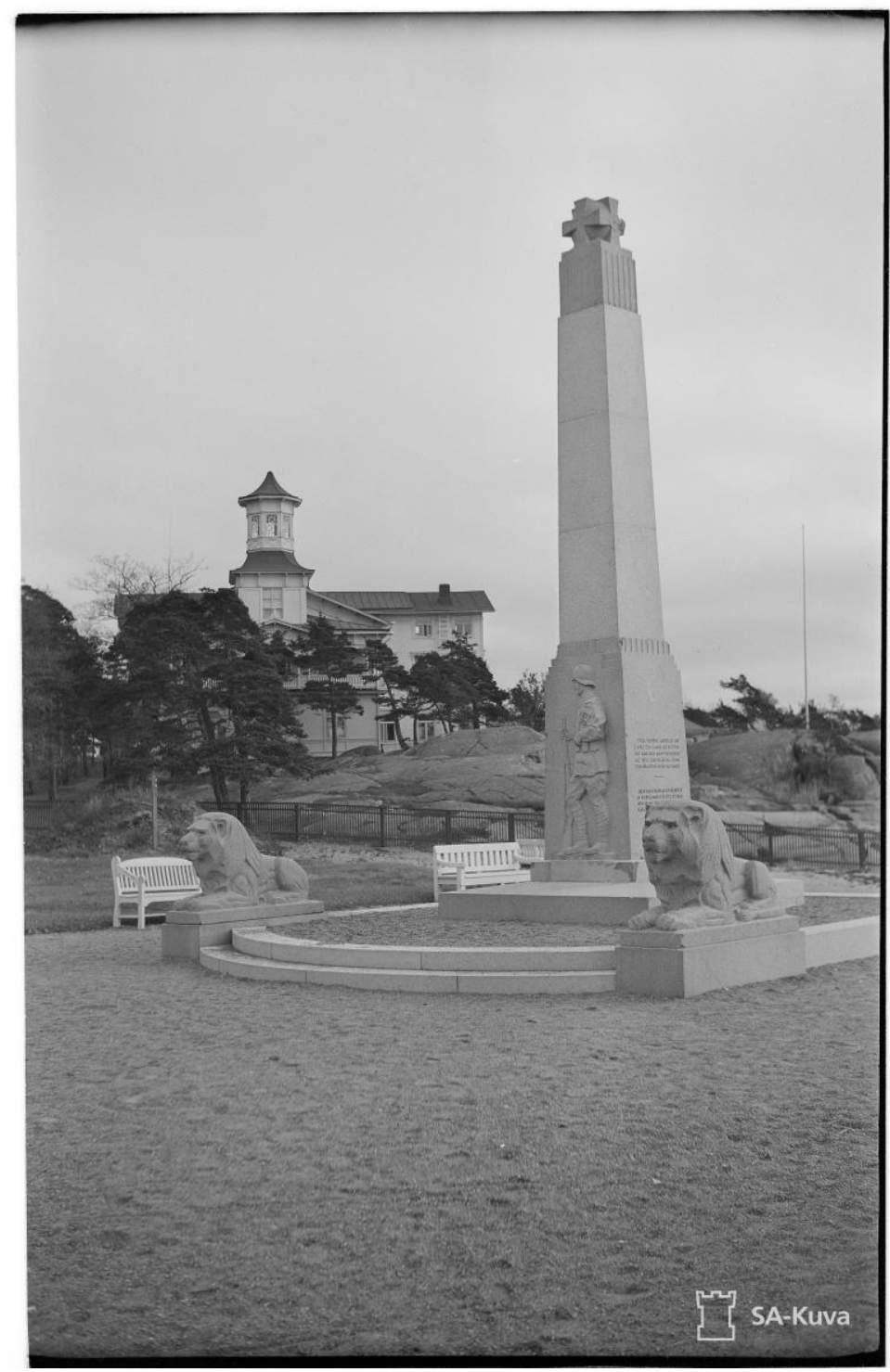
leen v. 1943 todistamaan kiitollisuutemme järkähtämättömyyttä." Tämäkin ikuistaminen jäi tilapäiseksi, sillä jatkosodan jälkeen Hangon vapaudenpatsaan saksalaissotilas, siis Neuvostoliiton vihollinen, oli liikaa ja patsaan poistamista vaadittiin. Uuden tulkinnan mukaan saksalaiset olivat "työväestön vihollisia" vuonna 1918 ja Neuvostoliiton vihollisia 1941-1945. Hankolaiset olivat tosin oma-aloitteisia ja patsas purettiin paikallisten toimesta jo ennen virallista määräystä, mutta sen osat säilytettiin. Patsas pystytettiin kolmannen kerran uudestaan vuonna 1960 ilman juhlallisuuksia, jolloin saksalaissotilaan reliefi hiottiin pois ja teoksen ainut ikuisuudelle tarkoitettu teksti oli ruotsiksi ja suomeksi "Vapautemme puolesta". ${ }^{88}$ Patsaan vaiheisiin tiivistyy täydellisesti vapaussodan perinnön mutkikkuus.

Kuva 4. Hangon vapaudenpatsas, saksalaisten vuonna 1918 kaupunkiin tekemän maibinnousun muistomerkeki undelleenpystytettynä 25. lokakunta 1943. Puretun patsaan osat löytyivät kaupungista. Kuva: SA-kuva 143184 


\section{Kolmikymmenluvun loppu ja toinen maailmansota}

Talvisota osoittautui, kuten tunnettua, merkittäväksi murrokseksi sisällissodan muistokulttuurissa. Etenkin punaisten aseman muuttuminen rikollisista ja pettureista "vakaumuksensa puolesta kaatuneiksi" merkitsi muistamisen kulttuurin muutosta. Murros oli kuitenkin jo meneillään 1930-luvun lopulla, kuten sovinnon viikkojen viettäminen osoittaa. Äärioikeisto oli ajautunut marginaaliin ja niin Maalaisliitto kuin jotkin konservatiiviset lehdet arvostelivat äärioikeiston juhlamenoja vieraina ja vanhentuneina. Esimerkiksi maalaisliittolainen lehti Kainuun Sanomat ehdotti ennen sotia termin "kansalaissota" käyttöönottamista vapaussodan tilalle ${ }^{89}$. Valkoinen historiankirjoituskin sai ennen talvisotaa punaisia sävyjä, kun esimerkiksi viimeisen elossa olevan punaisten rintamakomentajan, teatterijohtaja ja näyttelijä Jalmari Parikan (1891-1959) muistelmateos "Vïmeinen taisto": punaisen rintamapäällikön muistelmia v:lta 1918 julkaistiin vuonna 1938 valkoisten puolella taistelleen Uljas Rauanheimon (1898-1963) pyynnöstä.

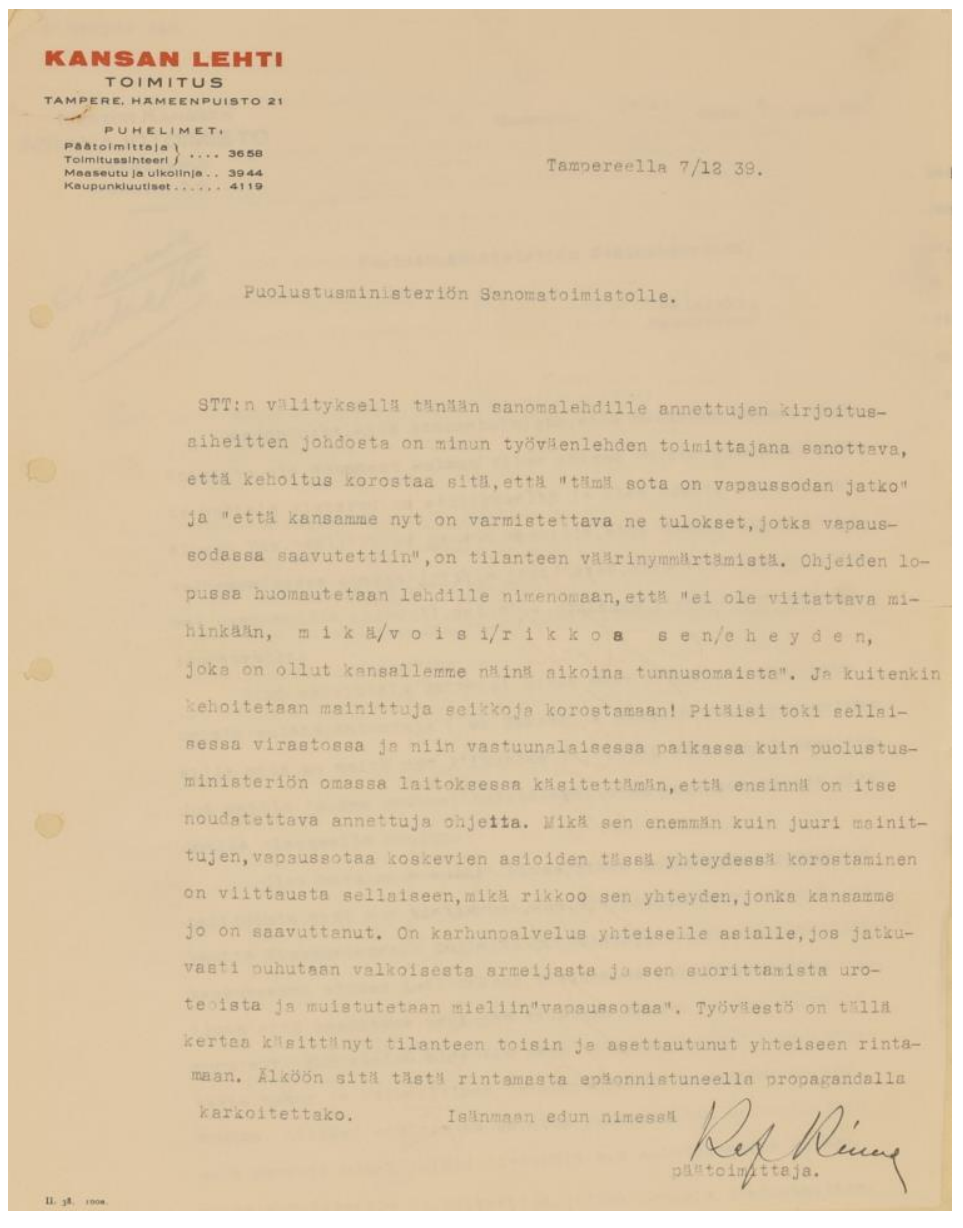

Kuva 5. Talvisodan pubjettua kamppailua Neuvostoliittoa vastaan rybdyttiin vertaamaan propagandamielessä vapaussotaan, mikä oli vieras rinnastus monille työväkeen kunluville. Sosialidemokraattisen Kansan Lebden päätoimittaja Rafael Rinne (1904-1978) kebotti 7.12.1939 Puolustusministeriön Sanomatoimistolle lähettämässään kirjeessä välttämään "vapaussodasta" tai "valkoisesta armeijasta" pubumista, koska ne eivät edistäneet kansakunnan eheytymistä. Kuva: Kansallisarkisto, Helsinki. Perus-3132/41. Рӓämaja. Sispropagandatoimisto (Prop.3). 81 Salainen kirjeenvaibto ja munt asiakirjat (19391940).

Talvisodan jälkeen Mannerheim kielsi järjestämästä perinteisiä puolustusvoimain lippupäivän juhlia ja määräsi uuden muistojuhlan toukokuun kolmanneksi sunnuntaiksi. Sitä tuli viettää "nyt päättyneessä sodassa kaatuneiden sankarivainajien sekä myös kaikkien murroskautena vuonna 1918 molemmin puolin vakaumuksensa puolesta henkensä uhranneitten yhteisenä uskollisena muistopäivänä”. Juhla nimitettiin yksimielisyyden, sankarivainajien tai kaatuneitten muistopäiväksi. Vaikka päiväkäsky toi esille, että molemmin puolin taisteltiin vakaumuksen puolesta, käsite 'vakaumuksensa puolesta kuollut' alkoi pian viitata punaisiin vainajiin..$^{90}$ 
Mannerheimin vetoomus ei mennyt kaikilla läpi. Toisen maailmansodan aikana äärioikeisto, kuten Rintamamiesliitto, piti yhä kiinni vapaussodastaan muistellen tammisunnuntaita ja voitonpäivää 16. toukokuuta. Vapaussodan suuret juhlat 1943 jäivät kuitenkin laimeiksi. Suomalaisia ei enää kiinnostanut juhlia ja muistella tapahtumia yhdestä näkökulmasta, pitihän sotapropagandakin yhtenäisyyttä tärkeänä. Lisäksi Valpo seurasi kaikkea toimintaa, joka saattaisi haitata yhteisiä sotaponnisteluja. Rintamamiesliitto myös kritisoi puolustusvoimien lippujuhlan siirtämistä toukokuun 16. päivästä kesäkuun neljänteen. ${ }^{11}$

Sodan aikana nimensä muuttaneessa Rintamamiehessä muisteltiin "Pohjalaisten suurta nousua Tammisunnuntaina 1918” (29.1.1943). Myös venäjänsaarelaisia kokoontui Helsingissä 21.1.1943 toveriiltaan. ${ }^{92}$ Liiton lehti Rintamamies oli myös kritisoinut seppeleiden laskemista entisten vihollisten haudoille, esimerkiksi itsenäisyyspäivän alla 1942, jolloin lehti puuttui varsinaisesti vapaussodan "unohtamiseen": "Huomista itsenäisyysjuhlaa valmisteltaessa on yksinpä maanpuolustusjärjestöjen äänenkannattajassakin jaoiteltu itsenäisyystaistelumme vaiheet itsenäisyysjulistukseen, talvisotaamme ja nykyiseen sotaamme. Poliittisista syistä halutaan unohtaa, että itsenäisyytemme tosin julistettiin joulukuun alussa viisikolmatta vuotta sitten, mutta todellisuudessa toteutettiin seuranneena talvena käydyssä vapaussodassa, joka totisesti on myöskin eräs itsenäisyystaistelumme vaihe. Sensijaan muistetaan kyllä laskea seppeleet niiden haudoille, jotka taistelivat vihollisemme puolella silloin. Jokainen hauta saakoon seppeleensä, sillä hauta vihan sovittaa. Mutta päivän valinta sen laskemiseen pitäisi olla hiukan harkitummin valittu."93

Jatkosodan aikana moni entinen vapaus/heimosoturi näki toisaalta toiveunensa Suur-Suomen toteutuvan ja Itä-Karjalan sotilashallinnon palkkalistoille päätyikin moni alueella 1918-1921 sotinut tai sieltä Suomeen paennut. Sota tiesi unelmien täyttymyksen lisäksi myös vapaussoturien ajautumista entistä pahemmin marginaaliin, vaikka vapaussotakytköksiä uuden ja vanhan sodan välillä tiiviisti etsittiin ja esiteltiin. Unelmat kuitenkin murskautuivat 1944 ja kansa eheytyi toisessa maailmansodassa vapaussotureista huolimatta, eikä heidän ansiostaan.

\section{Kylmä sota}

II maailmansodan päätyttyä aikaisemmin Suomessa kielletty, Moskovassa vuonna 1918 perustettu Suomen Kommunistinen Puolue laillistettiin ja kevään 1945 eduskuntavaaleissa puolue sai kattojärjestö Suomen Kansan Demokraattisen Liiton (SKDL) alla huomattavan äänisaaliin. Vasemmiston nousu näkyi ennen kaikkea omina muistomerkkihankkeina ja julkaisuina. Suomi oli välirauhansopimuksessaan Neuvostoliiton kanssa sitoutunut hajottamaan "fasistiset järjestöt", kuten Rintamamiesliiton ja suojeluskunnat, mikä tiesi monen vapaussodan perinnönvaalijan katoamista tai muuttumista. Suojeluskuntien omaisuuden säätiöimisen vanavedessä syntyi esimerkiksi edelleen toimiva Varsinais-Suomen Maakuntasäätiö, joka esittelynsä mukaisesti "vaalii suojeluskuntaperinteitä ylläpitämällä Turussa sijaitsevassa toimitilassa perinnetilaa ja jakamalla luotettavaa historiatietoa suojeluskuntajärjestöstä. Säätiön perinnetilaan on koottu kattava kokoelma suojeluskunta- ja lottaperinteeseen liittyviä esineitä, mm. pukuja, varusteita, kunnia- ja ansiomerkkejä, palkintoja, kuvia, kirjallisuutta sekä suojeluskuntien aikanaan käyttämiä aseita.” Moni muukin suojeluskunta tai vastaava taho sïrsi säätiöimällä perinnekokoelmansa eteenpäin ${ }^{94}$.

Välirauhansopimus ulotettiin myös suomalaisiin muistomerkkeihin. Aikaisemmin mainitun Hangon kahdesti puretun ja kolmasti pystytetyn muistomerkin lisäksi sotien jälkeen tapetille nousi kuusi muuta suomalaista muistomerkkiä, joita puitiin Hangon ohella hallituksessa 18.11.1946: Aunuksessa kaatuneitten hautakivi Turun Uudella hautausmaalla, Porin heimosoturihautapatsas, Pöytyän sankaripatsas, Kärsämäen Harjumäen patsas, Pulkkilan muistopatsas sekä Tornion taistelun muistomerkki. Muutokset olivat maltillisia, vaikka myös teosten poistamista esitettiin kommunistiministerien puolelta. Esimerkiksi 
Pulkkilan taistelun muistomerkissä sana "ryssä" korvattiin "vihollisella", Tornion taistelun patsaasta poistettiin sana "perivihollinen" ja Porin heimosoturipatsaasta poistettiin Suur-Suomeen viittaava teksti. Turun hautakivi ja Pöytyän sankaripatsas saivat jäädä koskemattomaksi. ${ }^{95}$

Sotien jälkeen akateemisessa historian kirjoittamisesta pitivät huolen lähinnä sotien välisenä aikana koulutuksensa saaneet historioitsijat, jotka joko vaalivat valkoista tulkintaa tai eivät ainakaan halunneet keinuttaa venettä ${ }^{96}$. Poikkeuksena valtavirrasta Juhani Paasivirta (1919-1993) julkaisi Suomi vuonna 1918 teoksen vuonna 1957, joka oli ensimmäisiä tasapuolisia katsauksia sotaan. Valkoisen historiatulkinnan hegemonia jatkui pitkälle 1960-luvulle, kunnes Väinö Linnan Täällä Pobjantähden alla -trilogia kaunokirjallisella rintamalla sekä Jaakko Paavolaisen tutkimukset sodanaikaisesta terrorista historiantutkimuksen saralla mursivat sen. Väinö Linna kieltämättä avasi keskustelun sisällissodasta ja punaisten historiantulkinnasta, mihin valkoiseen historiankirjoitukseen sitoutuneet professorit eivät ryhtyneet, mutta samalla Linna loi oman historiallisen myyttisen tulkinnan sisällissodasta torpparisotana. Viljo Rasila korosti vuonna 1968, ettei torppariongelma ollut olennainen sodan syttymiselle ${ }^{97}$.

Valkoisen tulkinnan murros näkyi myös muistojen keruutoiminnassa. Suomalaisen Kirjallisuuden Seura järjesti esimerkiksi vuonna 1948 keräyksen "Sotakaskuja vuodelta 1918". Oireellista on, että vuoden 1967 Mannerheim-kysely epäonnistui. Tarkoitus oli koota kansalaisten käsityksiä Mannerheimista, mutta esimerkiksi työväenlehdet eivät julkaisseet kyselyä laisinkaan. Aineistoa kertyikin todella vähän ${ }^{98}$. Vuoden 1917-1918 muistojen keruu järjestettiin vuosina 1965-1969 ja se tuotti 21000 sivua aineistoa 480 eri kertojalta. Hankkeen pohjalta kaavailtu kirjahanke Suomen 50-vuotisjuhlille kuitenkin vaiettiin kuoliaaksi ${ }^{99}$.

SKS:n keräämässä aineistossa kertojat ottavat osaltaan kantaa myös valkoisen historiantulkinnan puolesta. Esimerkiksi vuonna 1883 syntynyt maanviljelijä kirjoitti arkistolle: "Aivan väärän kuvan asioista antaa Väinö Linna Täällä pohjantähden alla teoksessaan. Olen itse mukana olleena nähnyt sotatapahtumia siksi paljon että Linnan antama kuva jääkärien toimeenpanemista joukkoteloituksista on liioiteltua. Raaemmat murhamiehet kyllä teloitettiin se oli tilanteen vaatima toimenpide vaan sodan rautainen ruoska ja kuoleman pelko hillitsivät villiintyneet ryövärilaumat (...) Linnan näkemys ei liioin pidä paikkaansa kyllä se oli pääosaltaan Turun, Helsingin ja Viipurin roskajoukkoa."100

Jatkuvuutena valkoiselle perinnölle tammisunnuntain vietto jatkui Pohjanmaalla 1950-luvulla, mutta muuten vuoden 1918 laajempi muistojuhlinta valkoisesta näkökulmasta hävisi. Valkoisen, vuonna 1944 kadonneen Suomen perintöä jatkoivat kyllä useat säätiöt ja yhdistykset. Vapaussodan rintamamiesliitossa toimineet perustivat vuonna 1954 Tampereella Vapaussoturien Huoltosäätiön ja vuonna 1959 alkoi ilmestyä säätiön tiedotuslehti, Vapaussoturi ${ }^{101}$.

Olennaista oli valkoisen historiantulkinnan pohjan katoaminen uudessa ympäristössä, missä tärkeää oli sankarivainajien aseman muutos. Jo talvisodan aikana kaatuneiden muistopäivän juhlaan kuului alkuun osan päivää kestävä suruliputus. Tapa vakiinnutettiin vuonna 1977 ja muutettiin normaaliksi liputuspäiväksi toisen maailmansodan loppumisen 50-vuotisjuhlana vuonna $1995^{102}$. 


\section{Kylmän sodan lopulla ja sen jälkeen}

Kylmän sodan päätyttyä itäblokin katoamiseen Neuvostoliiton romahduttua 1990-luvun Suomea luonnehti uusisänmaallisuuden käänne. Tämä tosin sai käytännössä alkuja jo 1980-luvulla, jolloin monista toisen maailmansodan vaiheista ja tätä edeltäneistä järjestöistä kirjoitettiin Suomessa perusteokset, kuten neliosainen Talvisodan historia I-IV tai Vilho Lukkarisen vuonna 1981 julkaisema Suomen lotat: Lotta Svärd -järjestön historia. Kylmän sodan päätyttyä myös oikeiston vapaussota sai uusia tuulia purjeisiinsa, vaikka pääosassa 1990-luvulla olikin II maailmansodan kokeneen sukupolven "kunnianpalautus".

Vapaussotatulkinta näkyi muun muassa Helsingin Sanomien kirjoituksissa, kuten kesäkuussa 1990 Simopekka Nortamon kirjoituksessa 'Vapaussota 1918': 'Jos kaikki tämä jossittelu - - hyväksytään todennäköisyydeksi, niin kaikkien meidän suomalaisten - oli aatetaustamme sitten punainen tai valkoinen - on tänä päivänä syytä olla hyvillään siitä, että valkoiset voittivat 1918.” Nortamo ei kuitenkaan vaikene punavankien kohtalosta sodan jälkeen eikä vähättele näiden kokemaa kärsimystä, mikä on luonteenomaista vanhemmalle vapaussotamyytin ylläpidolle ${ }^{103}$. Merkittävään asemaan nousi sisällissodan 75 -vuotispäivän vietto, etenkin sen päätapahtuma, joka järjestettiin Seinäjoella. Puheessaan pääministeri Esko Aho (Keskusta) esitti tervehdyksessään "kansakunnan kiitoksen vapaussotureille". Myös toukokuun 16. päivän muiston elvyttäminen aloitettiin 1990-luvulla, ja samalla alkoi suojeluskuntajärjestön ja Lotta-Svärdin maineenpalautus. On kuitenkin huomattava, että uusisänmaallisuus keskittyi lähinnä "turvalliseen" toiseen maailmansotaan ${ }^{104}$.

Suojeluskuntien maineenpalauttamisen lisäksi 1990-luvulla alettiin ajamaan varsinaista suojeluskuntajärjestön uudelleenperustamista ${ }^{105}$, mutta hankkeet eivät ottaneet tuulta purjeisiin. Kansalaisaloitetta järjestön jälleen perustamisesta kannatti vain 375 henkilöä. Muutkin, äärioikeiston ajamat yritykset vanhojen vapaussodalle rakentuneiden liikkeiden uudelleenperustamisiksi ovat jääneet marginaalissakin marginaaliin. Varsinaiset liikkeet valkoisen Suomen rehabilioinniksi jäivät vähäisiksi, mutta keskustelu sisällissodasta vapaussotana palasi näyttämölle ${ }^{106}$. Samalla kuitenkin sisällissota, tutkimuksellisesti ja poliittisesti sitoutumaton tulkinta vuoden 1918 tapahtumista, on noussut sen päänäyttelijäksi.

Uusisänmaallinen käänne on nähtävissä myös akateemisessa historiankirjoituksessa, ja etenkin vanhemmat tutkijat vahvistivat vapaussotatulkintaa ${ }^{107}$. Historioitsija Ohto Manninen perusteli Historiallisessa Aikakauskirjassa 1993 vapaussotakäsitettä kolmella argumentilla: Ensinnäkin venäläiset osallistuivat sotaan punaisten puolella, toiseksi Suomen ja Venäjän välillä oli sotatila ja kolmanneksi Manninen spekuloi mahdollisella Suomen asemalla, mikäli punaiset olisivat voittaneet sodan ${ }^{108}$.Vapaussotatulkinta on pitänyt pintansa 2000-luvulle asti, ja vaikka sodan tulkinta kansallisena murhenäytelmänä on korostunut ja etualalla, nähdään sota myös julkisissa puheenvuoroissa olennaisena Suomen demokraattiselle kehitykselle kuten eduskunnan puhemiehen Sauli Niinistön puheenvuorossa Finlandia-talossa vuonna $2008^{109}$.

Vapaussotatulkinnan taakse ryhmittyi myös perinneyhteisöjä ja aktivisteja. Vuonna 1993 perustettiin Vapaussodan Perinneliitto jatkamaan vuonna 1954 perustetun Vapaussoturien huoltosäätiön perinnetyötä. Perinneliiton ja sen jäsenjärjestöjen järjestämissä tilaisuuksissa on juhlistettu muun muassa vapaussodan alkua ja päättymistä, sekä Tarton rauhansopimusta, joka solmittiin $14.10 .1920^{110}$. Viimeisen juhlintaan liittyy mielenkiintoinen ero verrattuna 1920-luvun äärimmäisiin valkoisiin, jotka pitivät Tarton rauhaa häpeärauhana, koska siinä menetettiin Porajärven ja Repolan alueet. Vapaussodan Perinneliiton verkkosivuilla on oma sivu Täsmätietoa Vapaussodasta ${ }^{111}$, jossa sodasta kerrotaan muun muassa otsakkeiden "Punakaartien maanpetos", "Valkoiset syyttömiä kurjiin elinoloihin", "Harhaanjohtava propaganda julmuuksista" tai "Sodan lopputuloksena Suomen vapaus" alla. 
Myös vapaussodan muistojen keruu jatkui kylmän sodan päätyttyä. Salossa avattiin vuonna 2000 Itsenäisyyden museo, joka sai alkunsa Vapaussodan ja Itsenäisyyden Salon Seudun Perinneyhdistys ry:n ryhdyttyä 1990-luvun alussa vapaussotaan, suojeluskuntaan, lottajärjestöön ja vuosien 1939-1945 sotiin liittyvän materiaalin keräilyyn. Museon sivujen mukaan sen kokoelmiin kuuluu neljä ryhmää esineistöä: kunniamerkkejä, militariaa (deaktivoituja aseita ja muita sotilasvarusteita), asusteita ja muita esineitä sekä arkisto, johon kuuluu 50 mappia erilaista aineistoa sekä muun muassa videotallenteita. ${ }^{12}$ Vapaussotateema on aktivoitunut myös uusien muistoesineiden osalta. Sota näkyy myös hautausmailla, minne vuonna 1918 valkoisten puolella osaa ottaneiden hautakiviin on ilmestynyt "Vapaussoturin hautamerkkejä”, joita Vapaussodan Perinneliitto välittää ${ }^{113}$.

Sisällissodan 100-vuotismuistovuoden lähestyessä nähtiin, kuten Tïna Kinnunen huomauttaa artikkelissaan 'Sisällissodan muistokulttuuri kylmän sodan jälkeen: uusvanhoja ja uusia tulkintoja' (2018), valkoisten voittoa Suomen onnena korostavia kirjoituksia. Seikko Eskola kirjoitti aiheesta jo 90 -vuotisjuhlien yhteydessä vuonna 2008 ja Kalevan toimittaja Kyösti Karvonen pohti asiaa kirjoituksessaan toukokuussa $2017^{114}$. Sisällissota kytkeytyi myös laajempiin konteksteihin 2000-luvulla maailmalla voimistuvan nationalismin sekä eri puolilla maailmaan puhjenneiden sisällissotien annettua näkökulmia keskustelulle ${ }^{115}$.

Vapaussotatulkinnan muutokselle olennaista oli, ettei valkoista terroria tai punaisten kärsimyksiä sisällissodan jälkeen enää haluttu - tai voitu - kieltää, mutta keskustelussa niitä vapaussotatulkinnan innokkaimpien kannattajien keskuudessa joko vähäteltiin tai valkoisten rangaistustoiminta nähtiin välttämättömänä ja/tai oikeutettuna. Samalla moni on kokenut, että vastaavasti punaisten omaa terroria on ryhdytty vähättelemään julkisessa keskustelussa. Tätä on alleviivannut muun muassa Pentti Pylkkö teoksessaan Punainen viima. Punaisten väkivalta 1917-1918 (2016). Samaa pohtivat ohimennen myös Lasse Lehtinen ja Risto Volanen teoksessa 1918: Kuinka vallankumous levisi Suomeen (2018).

Keskeistä valkoiselle perinnölle on Suomen sisällissodan jälkeisen demokraattisen kehityksen korostaminen ja vaihtoehdon, Neuvostoliiton vasalliksi punaisten myötä joutuneen Neuvosto-Suomen aseman pohtiminen. Pohdinta jää kuitenkin usein abstraktiksi ja vaihtoehtoista, toteutumatonta historiaa on tietysti mahdotonta todistaa vääräksi tai oikeaksi. Korkeintaan voi spekuloida todennäköisyyksillä. Oireellista vapaussodan vaikeudelle 1990-2000-luvuilla onkin keskittyminen, kuten useasti mainittua, toiseen maailmansotaan, "toiseen ja kolmanteen vapaussotaan" joihin varsinainen vapaussotakin linkitetään. Tie tähän on kuitenkin ollut pitkä ja kaikkea muuta kuin mutkaton ja mäetön.

\section{Loppukatsaus}

Vapaussodan perintöön ja toisaalta siihen ripustautuneeseen oikeistoradikalismiin liittyi tietoisia kulttuurin ja muiston luomisen pyrkimyksiä. Paikalliset muistojuhlien valinnat ja muistomerkkihankkeet korostivat paikkakuntien omaa asemaa vapaussodassa, mikä muokkasi vapaussodan perinnöstä valtakunnallisen kansakunnan rakentamisprojektin ohella paikallisen identiteetin ja muistin rakentamiskeinon.

Ajallisesti valkoisten perinnössä on selkeitä muutosajanjaksoja. Kaiken alkuna oli luonnollisesti vapaussota 1918, mutta siinä konkretisoitui odottamattomilla ja jopa nurinkurisilla tavoilla jo aikaisempien vuosien työ, ja itsenäisyystaistelun aikaikkunaa venytettiin myöhemmissä tulkinnoissa kauemmas menneisyyteen.

Valkoisten perinteiden luominen ja muistamiskulttuuri alkoi sodan lopulla punaisten rintamien murentuessa, mutta sodan jälkeen valkoinen Suomi ajautui monella tavalla kriiseihin syksystä 1918 vuoteen 1919, minkä vastareaktiona syntyi uusi valkoinen rintama. Muistaminen kattoi niin muistin paikkojen 
luomisen kuin varsinaisten muistojen keruun. Seuraava vuosikymmen oli jyrkkää kahtiajaon aikaa, joka huipentui oikeistoradikalismiin eli Lapuan liikkeeseen 1930-luvun alussa. Vapaussodan perintö näytteli näille olennaista osaa, mutta samalla äärioikeisto ajoi itsensä marginaaliin missä sitä kritisoivat vasemmiston lisäksi poliittinen keskusta ja useat konservatiivitkin.

Vaikka puhetta sovinnosta oli jo heti sodan jälkeen, alkoi laajempi valtakunnallinen sovinnon kulttuuri vasta 1930-luvun alussa vastareaktiona oikeistoradikalismille. Vapaussotamyyttiin tuli säröjä, mutta se ei vielä varsinaisesti murtunut vuosikymmeniin. Toinen maailmansota, "seuraavat vapaussodat" eli talvi- ja jatkosota paransivat olennaisesti sisällissodan haavoja. Tässä ympäristössä vapaussodan perinteiden kiihkeimmät vaalijat muun muassa Rintamamiesliitossa olivat veneen keinuttajia, eivät soutajia, saati sitten aluksen perämiehï. Rauhan myötä 1944 ne siirsivät lakkautettavien suojeluskuntien tavoin omaisuuttaan, tehtäviään ja kokoamaansa perintöä uusille yhdistyksille ja säätiöille.

Toista maailmansotaa seurasi kylmä sota, jonka aikana valkoinen tulkinta joutui pahimpaan kriisiinsä 1960-luvulle tultaessa. Kylmän sodan päättyminen 1990-luvulla Neuvostoliiton häviämiseen loi uusisänmaallisuuden aikakauden, jonka yhteydessä alkoi myös vapaussodan rehabilitointi. Arvolatautunut vapaussota ei kuitenkaan pystynyt syrjäyttämään neutraalimpaa sisällissotaa, mutta valkoisten näkemys sopeutui omilla keinoillaan uuteen ympäristöön.

Uusisänmaallisuuden aikakautena 1990-luvulta alkaen moni sisällissotaan olennaisesti liittyvä valkoisen perinnön kappale on irrotettu vuoden 1918 kontekstista ja liitetty myöhempiin aikoihin, kunniakkaaseen II maailmansotaan. Sisällissodan laulut YouTubessa on kuvitettu Suomen lippujen lisäksi valokuvilla talvisodan ajalta. Samalla Lotta-Svärd ja suojeluskunnat on rehabilioitu lähinnä vuosien 1939-1944 näkökulmasta. Merkittävää on myös Mannerheimin tarkastelu kansallisen sovun rakentajana, minkä roolin hän otti verrattain myöhään, ja talvi- ja jatkosodan ylipäällikkönä.

Yli sata vuotta sisällissodan jälkeen vapaussodan perintö näyttää pitkällä ajalla tarkasteltaessa suoran tien sijaan suoranaiselta vuoristoradalta, joka tekee jyrkkiä mutkia, nousuja ja laskuja sekä aina silloin tällöin silmukoita, joista se kääntyy takaisin omille radoilleen. Sadan vuoden tarkastelussa nousee sen loppuajanjaksolla, 2000-luvulla, valkoisten vapaussodan puolesta yllättävän vähän puheenvuoroja ja argumentteja, joita ei olisi kuultu jo 1920-1930-luvuilla. Varsinainen perinnönkeruutyö on valkoisten puolella ollut pitkäkestoista ja laajaa. Toisaalta siinä on ollut selvä punaisten syyllisyyttä etsivä tarkoitus, ja samalla näkökulmia poissulkeva näkökulma, mutta se on myös kattanut hyvin laajan skaalan fyysistä ja henkistä perintöä. Seurauksena on valtava määrä aineistoa, jolla osaltaan vuotta 1918 voidaan tulkita uudestaan ja uudestaan. 
1 Suomen Vapaussota 20.3.1933.

${ }^{2}$ Miika Siironen, Valkoiset. Vapaussodan perintö (Tampere: Vastapaino, 2012).

3 Aapo Roselius, Isänmaallinen kevät: vapaussotamyytin alkuläbteillä (Helsinki: Tammi, 2013)

${ }^{4}$ Juha Poteri. Sankarihautaus vapaussodassa - valkoisten kaatuneiden hautaaminen Suomessa vuonna 1918 (Helsinki: PK-Koulutuskeskus, 2009).

5 Juha Poteri "Valkoisten sankarihautajaiset" Teoksessa Sisällissota 1918 ja kirkkoo toim Ilkka Huhta. (Helsinki: SKHS, 2009).

${ }^{6}$ Tuomas Tepora Sinun puolestas elää ja kuolla: Suomen liput, nationalismi ja veriubri 1917-1945 (Helsinki: WSOY, 2011).

${ }^{7}$ Tuomas Tepora ja Aapo Roselius (toim.) Rikki revitty maa: Suomen sisällissodan kokemukset ja perintö (Helsinki: Gaudeamus, 2018).

${ }^{8}$ Tiina Lintunen ja Anne Heimo (toim.). Sisällissodan jäljet. (Helsinki: Työväen historian ja perinteen tutkimuksen seura, 2018).

${ }^{9}$ Seppo Hentilä, Pitkeät varjot: muistamisen historia ja politiikkea (Helsinki: Kustannusosakeyhtiö Siltala, 2018).

${ }^{10}$ Roselius, Aapo, "Valkoinen rintama: Vapaussodan muiston vaalijat" teoksessa Rikkei revitty maa: Suomen sisällissodan kokemukset ja perintö toim. Tuomas Tepora ja Aapo Roselius (Helsinki: Gaudeamus 2018), 257-259.

11 Aapo Roselius. "Pyhä sota - suomalaiset heimosodat sisällissodan jälkimainingeissa". Teoksessa Rikki revitty maa: Suomen sisällissodan kokemukset ja perintö toim. Tuomas Tepora ja Aapo Roselius (Helsinki: Gaudeamus 2018), 259.

12 Siironen, Valkoiset. Vapaussodan perintö, 72.

${ }^{13}$ Roselius, "Pyhä sota - suomalaiset heimosodat sisällissodan jälkimainingeissa", 139-140.

14 Sumen Sosialidemokraatti 29.12.1934.

15 Suomen Vapaussota 15.6.1932.

16 Suomen Vapaussota 15.6.1932.

${ }^{17}$ Rintamamies: Vapaussodan rintamamiesten liiton äänenkannattaja. 20.11.1935

${ }^{18}$ Juha Siltala "Ratkaisuna sota, jota kukaan ei tahtonut". teoksessa Rikki revitty maa: Suomen sisällissodan kokemukset ja perintö toim. Tuomas Tepora ja Aapo Roselius (Helsinki: Gaudeamus, 2018), 72.

${ }^{19}$ Siltala, "Ratkaisuna sota, jota kukaan ei tahtonut", 79.

${ }^{20}$ Siltala, "Ratkaisuna sota, jota kukaan ei tahtonut", 75-76.

${ }^{21}$ Roselius, Isänmaallinen kevät: vapaussotamyytin alkulähteillä, 35-36.

22 Roselius, Isänmaallinen kevät: vapaussotamyytin alkuläbteillä, 17.

${ }^{23}$ Helsingin Sanomat 17.5.1918

${ }^{24}$ V. J. Marjanen. Turun rintamapataljoona (n. k. Uudenkaupungin suojeluskunta) vapaussodassa 1918. (Turku) $1928,317$.

25 Turun Sanomat 23.5.1918

${ }^{26}$ ks. Riku Kauhanen, ”Merimasku 1918” julkaisussa Myötätuulta Merimaskussa 30 (2018), 4-9.

${ }_{27}$ Roselius Isänmaallinen kevät: vapaussotamyytin alkulähteillä, 18-19.

${ }^{28}$ Kormano, Sotamuistomerk.ki Suomessa,57-58

${ }^{29}$ Siironen, Valkoiset. Vapaussodan perintö, 55-57.

${ }^{30}$ Roselius, Isänmaallinen kevät: vapaussotamyytin alkulähteillä, 29-30.

${ }^{31}$ Roselius, Isänmaallinen kevät: vapaussotamyytin alkuläbteillä, 39.

32 Hentilä, Pitkät varjot, 154, 156-157.

${ }^{33}$ Roselius, Isänmaallinen kevät: vapaussotamyytin alkuläbteillä, 55-58, 60; Hentilä, Pitkät Varjot, 156-157.

${ }^{34}$ Roselius, Isänmaallinen kevät: vapaussotamyytin alkuläbteillä, 67.

${ }^{35}$ Seppo Hentilä, "Vapaussota - valkoisen Suomen historiapoliittinen artefakti" teoksessa Sisällissodan jäljet toim. Anne Heimo ja Tiina Lintunen (Helsinki: Työväen historian ja perinteen tutkimuksen seura, 2018b), 339.

${ }^{36}$ Roselius, Isänmaallinen kevät: vapaussotamyytin alkulähteillä, 77-81.

${ }^{37}$ Roselius, Isänmaallinen kevät: vapaussotamyytin alkulähteillä, 92-93.

38 ks. Esko Nummelin "Itsenäisyys, nationalismi ja arkkitehtuuri Suomessa 1920- ja 1930-luvulla. Suojeluskuntajärjestö rakentajana" teoksessa Taidehistoriallisia tutkimuksia 12. (Helsinki: Taidehistorian seura, 1991).

39 Hakekapeliitta 28.1.1928.

40 Hakekapeliitta 28.1.1928.

41 Turun Sanomat 1.1.1935.

42 Tuomas Tepora, "Muuttuvat näkemykset vuodesta 1918” teoksessa Rikki revitty maa: Suomen sisällissodan kokemukset ja perintö toim. Tuomas Tepora ja Aapo Roselius (Helsinki: Gaudeamus, 2018), 308.

${ }^{43}$ Karjalan Sunta 2.1.1935

${ }^{44}$ Hämeen Kansa 5.1.1934

${ }^{45}$ Roselius, Isänmaallinen kevät: vapaussotamyytin alkuläbteillä, 42-43.

${ }^{46}$ Roselius, Isänmaallinen kevät: vapaussotamyytin alkuläbteillä, 41.

${ }^{47}$ Roselius, Isänmaallinen kevät: vapaussotamyytin alkulähteillä, 44-45.

${ }^{48}$ Roselius, Isänmaallinen kevät: vapaussotamyytin alkulähteillä, 45-46.

49 Anne Heimo ja Tïna Lintunen, "Luotauksia sisällissodan jälkiïn” teoksessa Sisällissodan jäljet toim. Anne Heimo ja Tiina Lintunen (Helsinki: Työväen historian ja perinteen tutkimuksen seura, 2018), 8.

${ }^{50}$ Riku Kauhanen, "Vuoden 1917 satoa Liedossa", Turun Tienoo 23.1.2018

51 Uusi Päivä 31.7.1918.

52 ks. Olli Kleemola ja R. Kauhanen, A. Kinnunen Käsin ja sydämin. Sota-ajan pubdetyöt (Karisto: Hämeenlinna 2019$), 14$. 
53 Anne Heimo ja T. Lintunen, ’Luotauksia sisällissodan jälkiin”, 8.

${ }^{54}$ Rintamamies: Vapaussodan rintamamiesten liiton äänenkannattaja 20.11.1935

55 Rintamamies: Vapaussodan rintamamiesten liiton äänenkannattaja 1.7.1933

56 Tampereen Sanomat 9.4.1918.

${ }^{57}$ Opettajain lebti: Kansanopetusta käsittelevä kuvallinen viikekolebti 29.11.1918

${ }^{58}$ Eemeli Hakoköngäs, ja O. Kleemola, I. Sakki, V. Kivioja "Remembering war through images: Visual narratives of the Finnish Civil War in history textbooks from the 1920s to the 2010s". Memory Studies. 1-16. 2020. https://journals.sagepub.com/doi/10.1177/1750698020959812 (käytetty 21.6.2021)

${ }^{59}$ Hakoköngäs et al., "Remembering war through images:", 6-8.

${ }^{60}$ Olli Kleemola "Sotienvälisen ajan kuvateosten sisällissota" teoksessa Sisällissodan jäljet toim. Anne Heimo ja Tiina Lintunen (Helsinki: Työväen historian ja perinteen tutkimuksen seura, 2018), 265-289.

${ }^{61}$ Kleemola, "Sotienvälisen ajan kuvateosten sisällissota", 267.

62 Kleemola, "Sotienvälisen ajan kuvateosten sisällissota", 270-275.

${ }^{63}$ Kleemola, "Sotienvälisen ajan kuvateosten sisällissota", 275-277.

${ }^{64}$ Kleemola, "Sotienvälisen ajan kuvateosten sisällissota", 277-278.

65 Kleemola, "Sotienvälisen ajan kuvateosten sisällissota", 283.

${ }^{66}$ Vesa Kurkela, "Sisällissodan laulut" Teoksessa Sisällissodan Pikkeujättiläinen toim. Pertti Haapala ja Tuomas Hoppu (WSOY: Helsinki, 2009), 425-440.

${ }^{67}$ Kurkela, "Sisällissodan laulut", 436.

${ }^{68}$ Emil Hällström vangittiin 1.5.1918 ja sai tuomion maanpetoksesta. Hän vapautui vankileiriltä, mutta menehtyi pian vankeuden aiheuttamiin rasituksiin. ks. Porin Työväen Soittokunta http://pts-band.fi/suuri-puhallinorkesteri/historia/ (käytetty 19.6.2021)

${ }^{69}$ Hakkapeliitta 11.9.1934.

${ }^{70}$ Itä-Savo 1.8.1918

${ }^{71}$ Kurkela, "Sisällissodan laulut", 430-431.

${ }^{72}$ Kurkela, "Sisällissodan laulut", 431.

73 Rintamamies: Vapaussodan rintamamiesten liiton äänenkannattaja. 20.11.1935

${ }^{74}$ Kaleva. https://www.kaleva.fi/tiernaperinne-ei-kaihda-uusia-vivahteita/1852238 (käytetty 19.6.2021); Mäkelä, Riitta. Kuninkaasta keisariin, Aleksanterista Mannerheimiin. Kaleva 22.12.2000

${ }^{75}$ Kurkela, "Sisällissodan laulut", 438-439.

76 Suomen Kuvalehti 30/1970. 25.7.1970.

77 Stump 3/1970.

${ }^{78}$ Youtube.com. Vöyrin marssi song. https://www.youtube.com/watch?v=VvDBKPADpT8 (käytetty 18.6.2021)

${ }^{79}$ Riitta Kormano, Sotamuistomerkeki Suomessa: voiton ja tappion modaalista sovittelua, Turun yliopiston julkaisuja. Sarja C, Scripta lingua Fennica edita, osa 396 (Turun yliopisto: Turku, 2014), 452.

${ }^{80}$ Roselius, Isänmaallinen kevät: vapaussotamyytin alkuläbteillä, 130-141.

${ }^{81}$ Kormano, Sotamuistomerk.ki Suomessa, 83-86.

${ }^{82}$ Rintamamies: Vapaussodan rintamamiesten lïton äänenkannattaja 20.11.1935

${ }^{83}$ Häme 27.10.1923

${ }^{84}$ Turun Sanomat 20.12.1924

${ }^{85}$ Kormano, Sotamuistomerkei Suomessa, 148-149.

${ }^{86}$ Vaasa 30.4.1926

${ }^{87}$ Roselius, Isänmaallinen kevät: vapaussotamyytin alkulähteillä, 132-133.

${ }^{88}$ Kormano, Sotamuistomerkei Suomessa, 408-412

89 Tepora, "Muuttuvat näkemykset vuodesta 1918", 306-307.

${ }^{90}$ Kormano, Sotamuistomerk,ki Suomessa, 26-27.

91 Tuomas Tepora, "Muuttuvat näkemykset vuodesta 1918". Teoksessa Tepora, Tuomas ja Roselius, Aapo (toim.) Rik.ki revitty maa: Suomen sisällissodan kokemukset ja perintö. (Helsinki: Gaudeamus) 2018, 312-314.

92 Rintamamies. Vapaussodan rintamamiesten liiton äänenkannattaja 29.1.1943.

93 Rintamamies. Vapaussodan rintamamiesten liiton äänenkannattaja 11.2.1942.

${ }^{94}$ ks. Kleemola tässä julkaisussa.

${ }^{95}$ Kormano, Sotamuistomerke. Suomessa, 409.

${ }^{96}$ Kinnunen, Tiina. Sisällissodan muistokulttuuri kylmän sodan jälkeen: uusvanhoja ja uusia tulkintoja. Teoksessa Tepora, Tuomas ja Roselius, Aapo (toim.) Rikki revitty maa: Suomen sisällissodan kokemukset ja perintö. (Helsinki: Gaudeamus) $2018,329$.

${ }^{97}$ Tepora, "Muuttuvat näkemykset vuodesta 1918”, 330.

98 Peltonen, Ulla-Maija. Punakapinan muistot: tutkimus työväen muistelukerronnan muotoutumisesta vuoden 1918 jälkeen (Suomalaisen Kirjallisuuden Seura: Helsinki, 1996), 65.

${ }_{99}$ Peltonen, Punakapinan muistot, 70.

100 Peltonen, Punakapinan muistot, 99.

101 Hentilä, Pitkät varjot, 285.

102 Kormano, Sotamuistomerkei Suomessa, 27.

103 Helsingin Sanomat 12.6.1990 
104 Kinnunen, "Sisällissodan muistokulttuuri kylmän sodan jälkeen", 341-342.

105 ks. Kleemola tässä julkaisussa.

106 Hentilä, Pitkät varjot, 286-287.

${ }^{107}$ Kinnunen ”Sisällissodan muistokulttuuri kylmän sodan jälkeen”, 343.

108 Ohto Manninen, "Vapaussota" julkaisussa Historiallinen Aikakauskirja 2/1993 (1993), 292-294.

109 Kinnunen, "Sisällissodan muistokulttuuri kylmän sodan jälkeen", 343.

${ }^{110}$ Kinnunen, "Sisällissodan muistokulttuuri kylmän sodan jälkeen", 342-343.

111 Vapaussodan perinneliitto. https://perinneliitto.fi/tasmatietoa-vapaussodasta/ (käytetty 17.6.2021)

112 Itsenäisyyden museo. https://itsenaisyydenmuseosalo.fi/museo/ (käytetty 21.6.2021)

113 ks. Vapaussodan Perinneliitto, Tuotteet. https://perinneliitto.fi/tuotteet/ (käytetty 23.6.2021)

114 Kinnunen, "Sisällissodan muistokulttuuri kylmän sodan jälkeen", 335-336.

115 Kinnunen, "Sisällissodan muistokulttuuri kylmän sodan jälkeen", 337. 